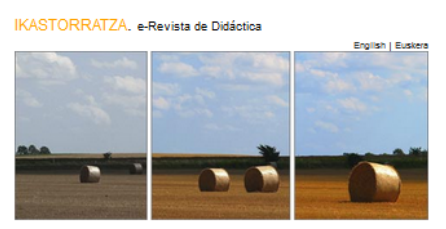

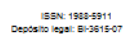

Inicio, Sobre nosotros, Publicacionesı, Participa

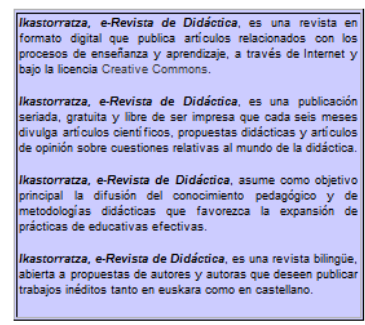

\section{IKASTORRATZA. Didaktikarako e-aldizkaria}

\author{
IKASTORRATZA. e-journal on Didactics
}

ISSN: 1988-5911 (Online) Journal homepage: http://www.ehu.eus/ikastorratza/

\title{
Uholde-arriskua hezkuntzan: Batxilergoko ikasleen ezagutza eta pertzeptzioak eta ikasgelarako proposamen didaktikoa
}

Claudia Pichot

claudiapichot@gmail.com

Oihana Barrutia oihana.barrutia@ehu.eus

Aritz Ruiz-González aritz.ruiz@ehu.eus

Unai Ortega-Lasuen unai.ortega@ehu.eus

José Ramón Díez

To cite this article:

joseramon.diez@ehu.eus

Pichot, C.; Barrutia, O.; Ruiz-González, A.; Ortega-Lasuen, U. \& Díez, J. R. (2019). Uholdearriskua hezkuntzan: Batxilergoko ikasleen ezagutza eta pertzeptzioak eta ikasgelarako proposamen didaktikoa. IKASTORRATZA. e-Revista de Didáctica, 23, 132-168. DOI: 10.37261/23_alea/6

To link to this article:

https://doi.org/10.37261/23_alea/6

Published online: 30 December 2019 


\title{
Uholde-arriskua hezkuntzan: Batxilergoko ikasleen ezagutza eta pertzeptzioak eta ikasgelarako proposamen didaktikoa
}

\author{
Claudia Pichot \\ Arabako Natur Zientzien Museoa. Fundadora de las Siervas de Jesús kalea, 24, 01001 \\ Vitoria-Gasteiz, Araba \\ claudiapichot@gmail.com
}

Oihana Barrutia

Matematika eta Zientzia Esperimentalen Didaktika Saila. Hezkuntza. Filosofia eta Antropologia Fakultatea. Euskal Herriko Unibertsitatea (UPV/EHU), Donostia-San

Sebastián

oihana.barrutia@ehu.eus

Aritz Ruiz-González

Matematika eta Zientzia Esperimentalen Didaktika Saila. Hezkuntza eta Kirola Fakultatea (Magistaritza atala). Euskal Herriko Unibertsitatea (UPV/EHU), Vitoria-

Gasteiz

aritz.ruiz@ehu.eus

Unai Ortega-Lasuen

Matematika eta Zientzia Esperimentalen Didaktika Saila. Bilboko Hezkuntza

Fakultatea. Euskal Herriko Unibertsitatea (UPV/EHU), Leioa

unai.ortega@ehu.eus

José Ramón Díez

Matematika eta Zientzia Esperimentalen Didaktika Saila. Bilboko Hezkuntza Fakultatea. Euskal Herriko Unibertsitatea (UPV/EHU), Leioa joseramon.diez@ehu.eus

\section{Resumen}

El objetivo de este trabajo es determinar el conocimiento y la percepción que posee el alumnado de $2^{\circ}$ curso de Bachillerato acerca del riesgo de inundabilidad. El estudio se ha realizado con estudiantes de tres centros educativos de la Comunidad Autónoma del País Vasco ubicados en ámbitos con diferente nivel de riesgo por inundación. Se testó la hipótesis de si el alumnado que previamente había cursado la asignatura Ciencias de la tierra y del medio ambiente poseía un mayor conocimiento y percepción acerca del riesgo de inundación. Los resultados muestran que, en general, existe una escasa percepción y conocimiento en torno a esta temática entre el alumnado. Por último, se ha diseñado una secuencia didáctica basada en la indagación que pretende desarrollar las competencias en torno a la gestión del riesgo por inundación. En dicha propuesta se atiende a los fenómenos de inundación como parte de la dinámica fluvial, proporcionando preguntas investigables, el uso de recursos digitales, la realización de pequeñas investigaciones, así como reflexiones y argumentaciones en torno a esta problemática socio-científica. 
Palabras clave: Bachillerato, Ciencias de la Tierra y del Medioambiente, riesgo de inundación, conocimiento, percepción, propuesta didáctica.

\title{
Laburpena
}

Lan honen helburua Batxilergoko 2. mailako ikasleek uholde-arriskuen aurrean dituzten ezagutzak eta pertzepzioak aztertzea da. Ikerketa uholde-arrisku maila ezberdinetako Euskal Autonomia Erkidegoko hiru ikastetxetako ikasleekin egin zen. Horretaz gain, Lurraren eta ingurumenaren zientziak irakasgaian uholde-arriskuak lantzen zituzten ikasleek ezagutza- eta pertzepzio-maila altuagoak ote zituzten testatu zen. Emaitzek erakutsi zuten ikasleen artean pertzepzio eta ezagutza eskasa zegoela gai honen inguruan. Azkenik, lan honetan uholde-arriskuen aurreko konpetentziak garatzeko asmoa duen eta indagazioan oinarrituta dagoen esku-hartze didaktiko bat diseinatu da. Bertan uholde-fenomenoak ibaiaren dinamikaren parte direla ikasten dira, ikasleek euren buruei galderak planteatuz, baliabide digitalak erabiliz, ikerketa txikiak eginez eta eztabaida soziozientifiko honen aurrean modu kritikoan hausnartuz eta argudiatuz.

Hitz gakoa: Batxilergoa, Lur eta Ingurumen Zientziak, uholde-arriskua, ezagutza, pertzeptzioa, proposamen didaktikoa.

\begin{abstract}
The aim of this study was to determine the flood-risk knowledge and awareness of students in their last year of baccalaureate studies. The study was conducted with three schools from the Basque Autonomous Community, which had different levels of flood-risk. In those schools there were some students who studied flood-risks in Earth and Environmental Sciences subject. Comparisons about students' perceptions and knowledge were made among the students who lived in places exposed to different levels of flood-risk. In addition, a comparison was made to know if the students who studied Earth and Environmental Sciences in school were more aware and had more knowledge about floodrisks. Results showed that overall there was little knowledge and risk perception among the students. Moreover, the study was focused on designing an inquiry based teaching and learning sequence about flood-risk, in order to enhance risk perceptions and knowledge. There, floods are studied as part of the streams' dynamics, where students ask questions to themselves, use digital resources, conduct small researches and critically reflect and argue about this socio-scientificissue.
\end{abstract}

Key words: Baccalaureate, Earth and Environmental Sciences, flood-risk, knowledge, awareness, educational proposal. 


\section{Sarrera}

Euskal Herriko isurialde Kantauriarrean ematen diren ibaien ur-goraldi eta uholdeen arrisku-maila handi samarra da Espainiar estatuko testuinguruarekin alderatuz (Ibisate, Ollero eta Ormaetxea, 2000). Euskal Autonomia Erkidegoko erliebeak eragiten du fenomeno hau, izan ere, euskal orografia menditsuak eta Penintsula Iberiarraren erliebeak euskal itsasertza Kantaurialdeko kostalderik euritsuena izatea dakar. Era berean, Euskal Autonomia Erkidegoko beste eskualde batzuetan, hala nola, Arabar Errioxan, prezipitazio hauek askoz ere urriagoak izaten dira (Euskalmet, 2011). Hala ere, prezipitazio kopurua ez da kontuan hartu beharreko parametro bakarra, izan ere, prezipitazioen iraupena ere garrantzitsua da. Gure eskualdean aldizka denetarik izaten dugu, euririk gabeko tarteak, lehorteak, izugarrizko euri-jasak edo zirimiria, alegia. Ekonomiaren aldetik, ordea, lehorteak baino, euri-jasak dira fenomenorik garrantzitsuena gurean. Izan ere, isurialde atlantiko osoan uholde larri eta garestiak eragiten dituzten fenomenoak dira (Euskalmet, 2011).

Uholdeak mundu osoan kalte handiak sortzen dituzten arrisku naturalak izanik (Bosschaart et al., 2016), administraziotik uholde-arriskuen azterketa eta kudeaketa egokia egiteko tresna ezberdinak martxan jarri ziren aurreko hamarkadan. 2007/60/CE zuzentarauaren arabera, Europako arro hidrografiko edo kudeaketa unitate bakoitzean, ondorengo ekintza hauek egin behar izan zituen 1. Irudian agertzen diren urtetarako:

1. Uholde-arriskuaren atariko ebaluazioa eta uholde-arrisku potentzial garrantzitsuko guneen identifikazioa

2. Arriskugarritasun mapak eta uholde-arriskuen mapak

3. Uholde-arriskua kudeatzeko planak

Europan osoan, eta gure eskualdean ere, uholdeek eragiten dituzten kalteak geroz eta larriagoak izaten ari dira (20/2016 Errege Dekretua). Eta hiru hamarkada barru, Europan aldaketa klimatikoaren eraginez bere maiztasuna bikoiztuko dela aurreikusi da (Alfieri et al., 2015). Izan ere, uholdeak arrisku natural bezala kontsideratzen baditugu ere, giza inpaktuek, hala nola, aldaketa klimatikoak, lurraldeen erabilera okerrak, uharren kontrolak, eta abarrek, uholdeak eragin ditzakeen kalteak larritu ditzakete (Wagener, 2007). Aurreko mendeko azken hamarkadetan gure herrialdean kalte hauek murrizteko asmoz egindako obra eta aldaketa ugarik zenbat egoera arindu badituzte ere, segurtasun sentsazio faltsua ere ekarri dute (Ibisate, Ollero eta Ormaetxea, 2000). Horrelako obrak egiten direnean, jendeak segurtasuna eta konfiantza sentitzen du eta arriskua egongo ez bailitzan jokatzen du (Bosschaart et al., 2016). Bestalde, kasu batzuetan hartutako neurri estrukturalek egoera hobetu beharrean, kaltetu egin dute. Hori dela eta, gaur egun indarrean dagoen plangintzaren erronkarik handiena uholde-arriskuak gutxitzeko neurri ezestrukturalak erabiltzea da. Izan ere, l e g e d i a r e n honen helburua uholde-arriskuko lurraldeak oker okupatzea saihestera bideratuta dago (20/2016 Errege Dekretua). 


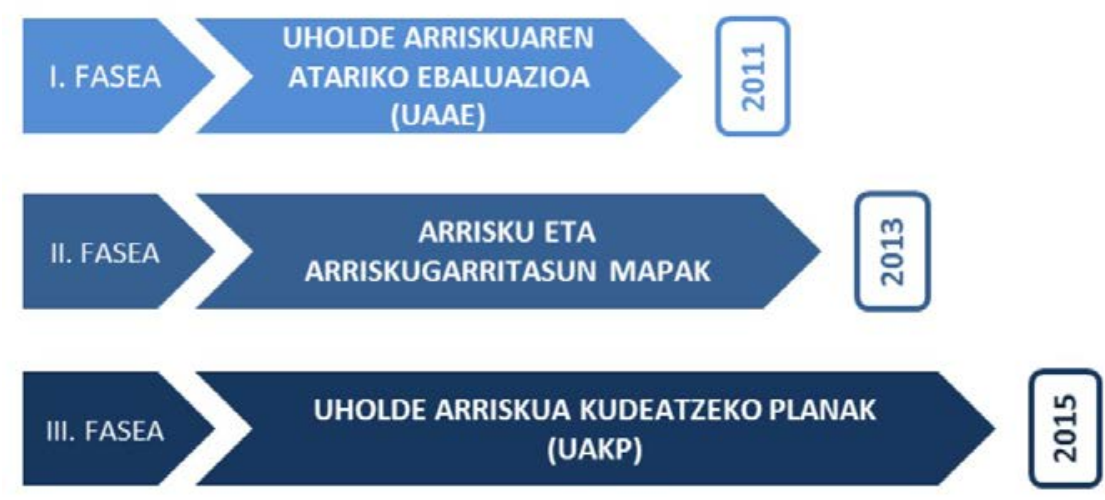

Irudia 1. 2007/60/CE zuzentaraua inplementatzeko ekintzak (20/2016 Errege Dekretua).

Estrukturalak ez diren neurrien artean, honako hauek aurki ditzakegu besteak beste: uholde-arrisku mailaren araberako erabilerak antolatzea, informazio hidrologikoko eta alerta goiztiarreko sistemak ezartzea, herri babeseko neurriak zehaztea (20/2016 Errege Dekretua) bai eta gizartea ahalduntzea edo gaitzea ere (Challies et al., 2016). Gizartea ahalduntzeko neurrien artean arrisku murrizketerako hezkuntza mundu osoko Eskola curriculumetan txertatzeko deia egin dute (Selby eta Kagawa, 2012). Izan ere, arriskuen gaineko ahalduntzeak eta heziketak onurak dakartzate haur eta gazteentzat, bai eta euren komunitateentzat, hondamendien aurreko erresilientzia handituz (Finnis et al., 2010).

Beraz, hezkuntzak berebiziko papera jokatu beharko luke arrisku naturalen kudeaketa egokiagoa egiteko, komunitate lokalen parte hartzea bultzatuz maila lokal zein globalean (Challies et al., 2016). Modu honetan, jendea prestatuago egoten da arrisku naturalei aurre egiteko, bai eta hauen ondorioak hobeto kudeatzeko ere (Wagner, 2007; Challies et al., 2016). Era berean, partaidetzaren bidez hartutako erabakiek kudeaketa hobea, plangintza-prozesuen legitimazio handiagoa eta ingurumen inpaktu txikiagoak dakartzatela ikusi da, administraziotik datozen erabakiekin konparatuz (Challies et al., 2016).

Orain arte, arrisku naturalen inguruko pertzepzioen ikerketak gehienbat helduengan zentratu dira, eta ikerketa gutxi egin dira gazte eta ikasleen artean (Bosschaart et al., 2013). Haatik, ikerlari askok eskolaren paperaren garrantzia nabarmendu dute. Izan ere, eskolek ezinbesteko papera har dezakete ikasleak arrisku naturalez, eta bereziki, uholde arriskuez ohartzeko (Bosschaart et al., 2013; Robles et al., 2015), bai eta familien ezagutza handitzeko ere (Bosschaart et al., 2013).

Gauzak horrela, lan honen helburu nagusia Batxilergoko bigarren mailako ikasleek uholdearriskuak maila orokor zein pertsonalean nola hautematen dituzten aztertzea da. Horretarako, uholde arrisku-maila ezberdina duten Euskal Autonomia Erkidegoko 3 hiriburuetako ikastetxe bana aukeratu da eta, bertan, galdetegi bat pasatu da haien pertzepzioak eta ezagutzak aztertzeko. Ikerketa hau Batxilergoko bigarren mailan egin da, izan ere, EAEko curriculum ofizialaren arabera, "Hidrosferaren dinamikarekin lotutako arriskuak: aurreikuspena, prebentzioa eta babes neurriak” Lurraren eta Ingurumenaren Zientziak irakasgaian lantzen da maila horretan (236/2015 Dekretua). Ikastetxe bakoitzean, beraz, galdetegia irakasgai hori hautatu duten ikasleei eta baita gainerako ikasleei ere pasatu zaie. Era horretan, trebakuntzak uholde arriskuaren gainean izan duen eragina aztertzea posible izan da.

Ikerketa honetatik lortutako emaitzak zein arloko bibliografia kontuan izanik, ikerketan oinarrituta 
dagoen esku-hartze didaktiko bat proposatzen da lan honetan, non uholde-arriskua sistema osoaren parte isolatu bat bezala landu beharrean, ibaiaren dinamikaren parte bezala lantzen den. Honen bidez, ikasleek uholde-arriskuen inguruan dituzten pertzepzioak eta ezagutzak handitzea bilatuko da.

\section{Oinarri teorikoa}

\subsection{Alfabetizazio zientifikoa}

Gaur egun, ikasleek oinarrizko hezkuntza amaitzen dutenerako, gai izan behar dute, ez soilik zientziaren oinarrizko ideiak ezagutzeko, baizik eta ezagutza horiek eguneroko bizitzako arazo konkretuen aurrean erabiltzeko eta gizakiak arazo horiengan duen paperaren inguruan erabakiak hartzeko ere (Aguerri eta Bravo-Torrija, 2017). Hori horrela, azken urteetan, gero eta garrantzia handiagoa ematen ari zaio eskoletan ikaskuntza esanguratsua lortzerari (Bach eta Márquez, 2017), hau da, ikasleek ikasten duten informazio berria aurretik zekitenarekin erlazionatzeko eta informazio guztia, zaharra eta berria, elkarlotzeko gaitasuna izateari (Ausubel et al., 1978).

Ikaskuntza esanguratsu hori lortu nahian, konpetentzietan oinarritutako ikaskuntzak indarra hartu du. Konpetentea izatea lan bat eraginkortasunaz burutzeko gaitasuna izatea da. Horrek esan nahi du lan hori egiteko ezagutzak izateaz gain, horretarako gaitasunak eta jarrera egokia izatea ezinbestekoa dela (2. Irudia) (Pedrinaci, 2013). "Konpetentea izateko, modu integratuan erabili behar dira norberak eskuratu dituen baliabideak, erronka edo arazo diren egoerak ebazteko (236/2015 dekretua, 79.or)”. Konpetentzia hauek eremu pertsonalean, sozialean, akademikoan eta lanbide-eremuan lortu behar direla zehazten du curriculumak (236/2015 Dekretua).

Honenbestez, ezagutza zientifikoaz mintzo garenean, gure kezka nagusia ezin da izan ikasleek eskolan ikasten dituzten ezagutzak erreproduzitzeko gai izatea, baizik eta ezagutza hori erabiltzeko gai izatea. Izan ere, erabilgarritasun horrek erakusten digu, benetan, ikasleek nolako ulermen-maila lortu duten (Pedrinaci, 2013).

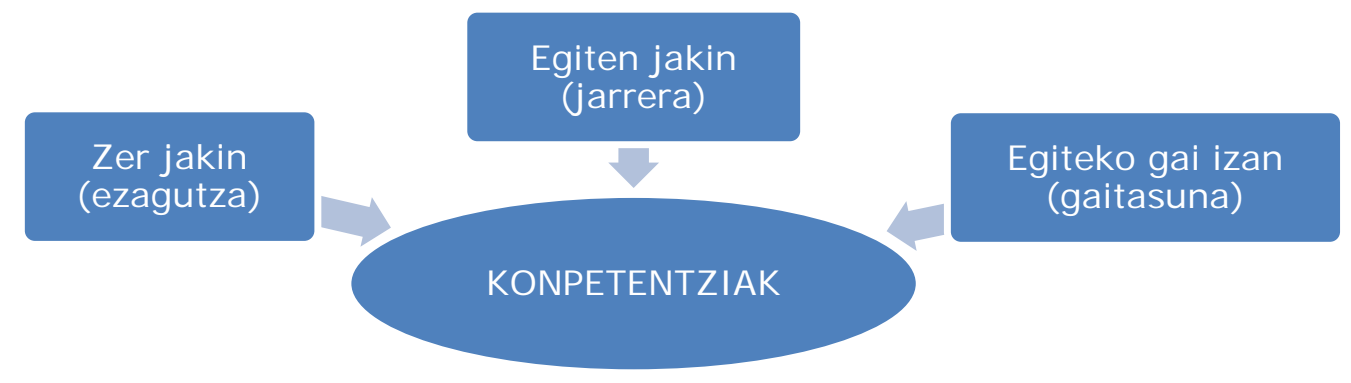

Irudia 2. Konpetentzietan oinarritutako ikaskuntzaren zutabeak: ezagutzak, jarrerak eta gaitasunak.

Zientziari dagokionez, ikasleek konpetentzia zientifikoa lortzeko ahaleginean, ikasketa-prozesu egokia ahalbidetzen duen giroa sortu beharra dago ikasgelan, non ikasleek disziplina honetakoak propioak diren trebeziak martxan jarri ahal dituzten, hala nola: analisirako gaitasuna, datuen interpretazioa edota ebidentzietan oinarritutako ondorioak lortzea. Eguneroko bizitzan, gure ingurunean sortzen diren arazoak konpondu nahian, ikasleek zientziak gizartean duen paper garrantzitsuaz jabetu daitezke (Aguerri eta Bravo-Torrija, 2017). Hezkuntza-ikuspuntu honi "alfabetatze zientifikoa" deritzo (Pedrinaci, 2013). Ikaskuntza-mota honek proposatzen dituen "benetako arazo" hauek honako ezaugarri hauek dituzte: 1) 
ikasleengandik gertu geratzen den testuingurua dute, 2) jakina den konponbiderik ez dute, eta 3) ikasleen arteko elkarrizketa eta elkarrekintza sustatzen dute (Aguerri eta Bravo-Torrija, 2017).

EAEko curriculumaren arabera, konpetentzia zientifikoa "zientziaren jakintza eta metodologia modu koherente, bidezko eta zuzen batez erabiltzea testuinguru esanguratsuetan sistema eta fenomeno naturalak interpretatzeko, eta aplikazio zientifiko eta teknologiko nagusiak erabiltzea askotariko testuingurutan, errealitatea ebidentzia zientifikoen argitara ulertzeko eta erabaki arduratsuak hartzeko bizitzaren esparru eta egoera guztietan” da (236/2015 Dekretua, 76.or).

Alfabetatze zientifikoari esker, ikasleak gai dira jakinmina sortzen dieten eguneroko bizitzako kontuei erantzuna emateko, bai eta fenomeno naturalak deskribatzeko, azaltzeko eta aurresateko ere. Horretaz gain, zientifikoki alfabetizatutako ikasle bat gai izango da jasotzen duen informazio zientifikoa kalitatez baloratzeko, informazioaren iturria eta hori lortzeko erabili diren metodoak kontutan hartuta. Hori dela eta, zientziaren alorrean garrantzitsuak diren gaien inguruan sortzen diren eztabaidetan parte hartzeko gaitasuna lortzeko aukera ematen die (Pedrinaci, 2013).

\subsection{Natur zientzietako modelo mentalak}

Ezagutza zientifikoa geroz eta zabalagoa da eta modu esponentzialean handitzen ari da. Horrek arazoak sortzen ditu eskola curriculumetan sartu behar diren edukiak aukeratzerako orduan (Bach eta Márquez, 2017). Gehiegizko eduki hauek, ikasleen motibazio falta dakarte zientzia arloan, ez baitute zientziaren garrantzia ikusten. Interes falta hau, batez ere, bigarren hezkuntzatik aurrera ematen da, non ideia zientifikoak geroz eta abstaktuagoak bilakatzen diren (Harlen, 2010). Motibazio edo interes murrizketa honi aurre egiteko ekimen ezberdinak sortu dira, eta korronte indartsuenek ikasleei zientziaren ideia nagusiak irakasteko beharra azpimarratzen dute (Bach eta Márquez, 2017), bai eta ideia horiek modelo mental egokien bidez deskribatzeko premia ere (Martínez eta Gil, 2014).

Modelo mentalak, sistema baten forma eta xedea deskribatu, sistemaren funtzionamendua azaldu eta sistemaren etorkizuneko egoerak aurresateko izaki bizidunok darabiltzagun pentsamendu-mekanismoak dira (Wagner, 2007; Martínez eta Gil, 2014). Beste modu batera esanda, modelo mentalak gertaera ezberdinen irudikapen mentalak dira (Martínez eta Gil, 2014). Esaterako, arrisku naturalen inguruan sortzen ditugunak esperientzia pertsonalean eta komunikabideetatik, erakundeetatik edota bestelako taldeetatik jasotzen dugun informazioan oinarritzen dira (Wagner, 2007). Hala ere, modelo mental egokiak lortzea ezinbestekoa da, eta horiek modelo zientifikoetara ahalik eta gehien hurbildu beharko genituzke. Izan ere, zientzia arloko modelo hauek eraikitzen eta konparatzen ikasteak, zientzien ikaskuntza-prozesua errazten du. Gainera, ideia ezberdinen aurrean modu oinarrituan argudiatzeko gaitasuna funtsezkoa da konpetentzia zientifikoa lortzeko (Martínez eta Gil, 2014). 
Modelo mental egokiak eraikitzeko ezinbestekoa da zientziako ideia nagusiak (big ideas of Science) edo ideia gakoak (core ideas) delakoak zehaztea (Bach eta Márquez, 2017). Ideia nagusi hauek ez dira teoria soilak, baizik eta progresio bat, bizitzan zehar garrantsitzuak izango diren gertaerak ulertzeko gako bihurtuko direnak (Harlen, 2010). Ideia nagusi hauen bidez bi helburu nagusi lor daitezke natur zientzien arloan. Batetik, Lur- sistema ulertzea, bertan gertatzen diren prozesuak eta prozesu horien elkarrekintzak ulertuz. Bestetik, ikasleen artean jarrera jasangarriak bultzatzea, Lurraren funtzionamenduan gizakiak eragindako inpaktuek duten eragina kontuan hartuta (Bach eta Márquez, 2017).

\subsection{Arriskuen kudeaketa eta eskolaren garrantzia}

Arriskuen kudeaketa, arrisku bat hondamendi bihurtu baino lehen, arriskuak sor ditzaketen faktoreak (mehatxuak eta zaurgarritasuna) minimizatzeko asmoz, gizarteak hartzen dituen neurrien multzoa da (Robles et al., 2015). Baina, zer kontsideratzen dugu arrisku bat? Arriskua hainbat modutara definitu daiteke, baina sarri, gizabanako batek ezbeharra sufritzeko probabilitatea bezala definitu izan da (Sjöberg et al., 2004). Beste era batera esanda, arriskua eremu geografiko konkretu batean, fenomeno natural batek sortutako ondorio sozial edo ekonomikoak gertatzeko probabilitatea da, aurretik zehaztutako baloreak berdindu edo gaindituz. Hau da, gertaera natural baten ondorioz, giza kalte edo kalte materialen probabilitatea estimatzen duen kontzeptu sozial eta ekonomikoa da (González et al., 2014).

Robles et al. (2015)-en ustez, arriskua fenomeno natural bat gertatzeko mehatxua eta zaurgarritasuna batera agertzearen ondorioa da. Hala ere, González et al. (2014)-k definizio osatuagoa ematen dute, arriskua erlazio honen bidez adieraziz:

$$
\text { Arriskua = mehatxua }{ }^{(1)} \mathrm{x}_{\text {zaurgarritasuna }}{ }^{(2)} \mathrm{x} \text { esposizioa }{ }^{(3)}
$$

Ekuazio honen arabera, mehatxua ${ }^{(\mathbf{1})}$, eremu geografiko eta denbora konkretu batean, hondamendia sor dezakeen fenomeno bat gertatzeko probabilitatea den, eta probabilitate hori fenomeno hori gertatzeko frekuentzia eta magnitudearekin erlazionatuta dagoen; zaurgarritasuna ${ }^{(2)}$, egitura edo eremu batean, fenomenoak eragiten duen kaltearen esperotako maila den; eta, esposizioa ${ }^{(3)}$, arriskuaren eraginpean dauden pertsona, ondasun, zerbitzu eta prozesuen multzoa den.

Behin arriskua definituta, aipatu beharra dago eskolek arriskuen kudeaketan duten paper garrantzitsua. Autore ezberdinek nabarmendu dute eskolek duten garrantzia ikasleen arriskuen pertzepzioak handiagotzen, eta baita, zeharkako modu batean bada ere, familiek izan ditzaketen usteak eta pertzepzioak bideratzen ere (Bosschaart et al., 2013; Bosschaart et al., 2016; Shaw et al., 2004).

Azken finean, Robles et al.-ek (2015) honela adierazi zuten eskolaren rola:

"Eskola komunitatearen erakusgarri txiki bat da. Horregatik, arrisku askorengatik kaltetua izan badaiteke ere, arrisku horiek sortzen dituzten faktoreei aurre egiteko estrategiak abiarazteko eszenatokia ere izan daiteke arriskuak gutxitzeko eta hondamendi bihurtzea ekiditeko asmoz (Robles et al., 2015, 1.or).”

Beraz, komunikabideez eta testuinguru sozialaz gain, hezkuntza formalak ezinbesteko rola hartzen du arriskuen kudeaketan, bai ezagutzak emendatuz eta baita arriskuarekiko ikasleek dituzten pertzepzioak bideratuz ere (Bosschaart et al., 2013). Izan ere, ezagutza hezkuntzaz gain esperientziatik badator ere, 
eskola oso erabilgarria da lehenengo pausu bezala, non ezagutzak lortzen diren eta ikasleen interesa pizten den (Shaw et al., 2004).

Arriskuen kudeaketa modu eraginkorrean egiteko, Nazioartean UNESCOk argitaratutako agirian, bederatzi arau jasotzen dira. Horien artean badira bi berebiziko garrantzia hartzen dutenak, batez ere prebentzio mailan, eta eskoletan aplikatu daitezkeenak (Sayers et al., 2013). Hauek dira:

a) Arriskuak eta ziurgabetasunak ulertzea erabakiak hartzeko oinarria da.

b) Arriskua eta ziurgabetasuna modu zabal eta eraginkor jakinaraztea. Arriskuak modu eraginkorrean adieraziz gero norbera hobeto prestatuta egon daiteke eta, behar izatekotan, arintzeneurrietarako laguntza jasoko luke.

Izan ere, eskoletan ikasleei uholde-arriskuen inguruko informazioa luzatuz gero, hauek gai izango dira etorkizunean erabaki zuzenak hartze k o eta, ahal izanez gero, arriskuak edota hauek eragiten dituzten kalteak aurreikusi edo murrizteko (Challies et al., 2016).

\subsection{Ikasleen pertzepzioak uholde-arriskuaren aurrean}

“Arriskuaren pertzepzioa istripu-mota jakin bat gertatzeko probabilitatearen eta egon daitezkeen ondorioekiko dugun ardura-mailaren ebaluazio subjektiboa da” (Sjöberg et al., 2004, 8. or). Orokorrean, helduek eta gazteek modu ezberdinetan hautematen dituzte arriskuak. Askotan esaten da nerabeek ez dutela uste ezer txarrik gertatu ahal zaienik, mina edo kaltearen aurrean hunki-ezinak direla. Honi "niri ez zait gertatuko” edo ingelesezko “it won't happen to me” fenomenoa deritzo. Bada, uste honek arriskuekiko irreala den baikortasunaren handitzea dakar gazteen artean (Bosschaart et al., 2013).

Arriskuaren aurrean prest egoteko, garrantzitsua da uholde-arriskuen pertzepzioan eragina izan dezaketen faktoreak aztertzea, bai eta prebentzioan lagun dezaketen faktoreak ere. Horrekin batera, gizartea, baita gazteak ere, arrisku pertsonalaren eta galera ekonomikoen gutxitzea dakartzaten ekintzak egitera bultzatu behar dira (Siegrist eta Gutscher, 2006), horrela baita gizarteak hobeto ikasten duen modua, komunitatean, hain zuzen ere (Pahl-Wostl, 2006). Orokorrean, arrisku baten probabilitatea neurtzerakoan, jendeak arrisku hori burura etortzeko erraztasuna kontuan hartzen du. Beraz, arrisku bat jasan izanak, arriskuarekiko pertzepzioaren handitzea ekarriko luke. Baieztapen hau bat dator ikerketa askoren emaitzekin, izan ere, esperientzia faktore garrantzitsu bat da jendearen arriskuen pertzepzioan (Siegrist eta Gutscher, 2006).

Esperientzia kontuan hartuta, erraza da ikustea helduek uholde-arriskuen aurreko hautemate-maila handiagoak izango dituztela. Bosschaart et al.-en ikerketan (2013) aipatzen den moduan, helduekin konparatuz, gazteek arriskuen pertzepzio murritzagoak dituzte eta zaurgarritasun uste txikiagoa dute. Bestalde, ikerketek diote arrisku esperientzia bat bizi izan arren, efektu pertsonal negatiborik izan ez bada, arriskuaren pertzepzioaren murrizketa handia dagoela (Siegrist eta Gutscher, 2006).

Ikerketen arabera, esperientziarekin batera, bada beste faktore bat ikasleen pertzepzioan eragin dezakeena. Faktore hori eskualde konkretu bateko arrisku-maila izango litzateke. Izan ere, arrisku handiagoko eskualdeetan, ikasleak kontzienteago dira arriskuetaz, eta gainera, ezagutza handiagoak dituzte, horiek gertatzekotan, hartu beharreko erabakietan (Siegrist eta Gutscher, 2006). Era berean, 
ikusi da uholde-arriskuen aurreko ezagutza gutxi dituzten pertsonek, arrisku-pertzepzio txikiagoak dituztela (Bosschaart et al., 2013).

Arriskuaren pertzepzioan eragin dezakeen beste faktoreetako bat ezagutza-maila da. Adituen arabera, ezagutzak beldurraren gutxitzea ekar dezake, arriskuarekiko ohitura hartzen delako, eta, lehen aipatu bezala, segurtasuna sumatzen delako. Bestalde, ezagutza falta dagoenean, segurtasun neurrienganako konfiantza handiagoa dagoela ikusi da (Bosschaart et al., 2013).

\subsection{Euskal Autonomia Erkidegoko gaur egungo egoera}

Historian zehar uholdeak izan dira Kantauriko Arro Hidrografikoaren esparruan kalterik handienak sortu dituzten arrisku naturalak; bai kalte materialak baita kalte pertsonalak ere. Uholde-arriskuen atariko ebaluazioan lortutako emaitzek erakutsi dute ziurgabetasun handia dagoela klima aldaketak euri modeloan duen eraginean. Horren ondorioz, zaila egiten da klima aldaketak uraldien maiztasunean eta neurrian eragingo duen aldaketa zenbatestea (20/2016 Errege Dekretua). Azkeneko hiru hamarkadetan arrisku naturalen gertaera ugari bizi izan dira gure zonaldean, bereziki muturreko gertakari atmosferikoak. Urte hauetan lehorte eta uholde garaiak tartekatzen joan dira behin eta berriro. Uholdeek eragindako kalte ekonomiko eta sozialak izugarri handiak dira estatu mailan, eta kalte hauek handiagoak izango direla aurresaten da klima aldaketaren eraginez (Olcina, 2009). Hala eta guztiz ere, badago kontsentsua klima aldaketak ekarriko dituen zenbait ondorioetan (20/2016 Errege Dekretua):

1. Probabilitate handiz, muturreko prezipitazioen gertaldiek maiztasun eta intentsitate handiagoa izango dute datozen urteetan. Hau ez da bakarrik Euskal Autonomia Erkidegoko arro hidrografikoetan gertatuko, baizik eta Espainiako eta Europako bestelako arroetan ere.

2. Aipatutako muturreko gertakari meteorologikoak, hala nola, ekaitzak eta uholdeak, biziagoak izango direla aurresaten bada ere, fenomeno natural hauen maiztasun eta intentsitatearen aldaketak zaila egiten du hauek epe laburrean identifikatu eta aurreikustea.

3. Euskal Autonomia Erkidegoan bezala, planeta osoko gainerako herrialdeetan ere, denboran zehar uholdeen kalteak gero eta handiagoak izango direla iragartzen da. Azken urteotako bilakaera ikusita, uholde gertaerak berdin jarraitzea edo gehiago izatea aurreikusten da.

Uholdeek datozen urteetan eragin ahal izango dituzten kalteak kontuan hartuta, eta hauek prebenitzeko edo gestionatzeko nahian, uholdeen ebaluazioa eta arriskuen kudeaketaz arduratzen den Uztailaren 9ko 903/2010 Errege Dekretua plazaratu zen. Dekretuaren 5. artikuluaren arabera, arro hidrografiko bakoitzean uholde-arriskuaren atariko ebaluazioa egin behar izan da, uholde-arriskua jasateko probabilitate handia duten eskualdeak determinatzeko. Hori egin eta gero, uholde-arrisku potentzial garrantzitsuko guneak ("Áreas con Riesgo Potencial Significativo de Inundación”, ARPSIs) identifikatu dira. Uholdeak jasateko arrisku nabarmena duten tokien artean, EAEko zenbait eskualde ageri dira (Irudia 3). 


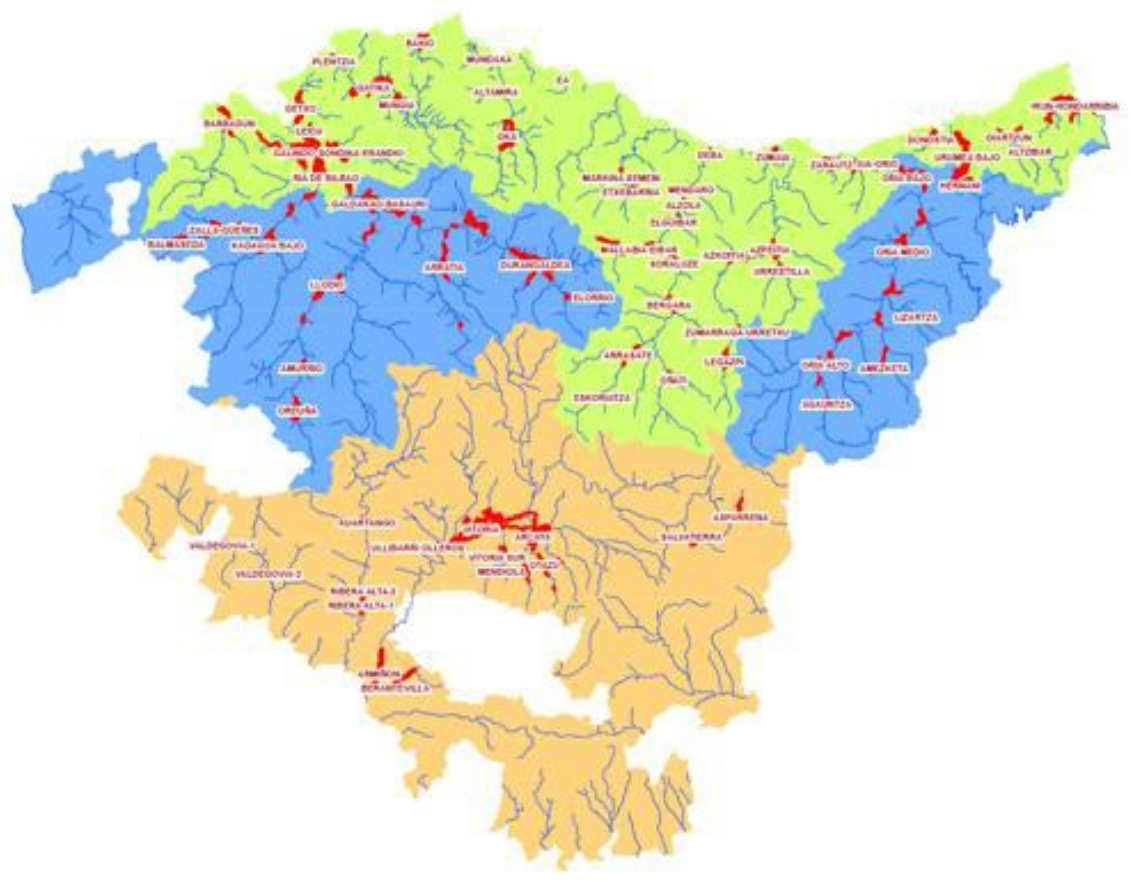

Irudia 3. Gorriz, EAEn uholde-arrisku potentzial garrantzitsuko guneak (ARPSIs) (Iturria: URA, Uraren euskal agentzia).

\subsection{Ibaien dinamika ikastearen garrantzia uholde-arriskuak ulertzeko}

XX. mendearen amaierara arte, arazo zientifikoei irtenbidea emateko metodo analitikoerredukzionista erabiltzen zen. Metodo honen bidez, arazo konplexuak arazo txikiago eta sinpleagoetan banatzeko joera zegoen. Hala ere, modu honetan arazo konplexuak ezin ziren konpondu, izan ere, unitate bat zati txikiagoetan deskonposatzen denean, zatitik at geratzen diren parteak ezin dira aztertu, eta lortzen diren emaitzak ez dira fidagarriak. Hala, arazo konplexuak bere osotasunean tratatzeko beharra ikusi zen (Bach eta Márquez, 2017).

Uholde-arriskuak ikasterakoan, ezin dugu ahaztu uholdeak ibaien, mendi uharren edo gainerako ur kontinentalen gainezkatzearen ondorioz sortzen diren aldi baterako urperatzeak direla. Gainera, fenomeno naturalak izanda, beharrezkoak dira ekosistemak egoera onean mantentzeko (20/2016 Errege Dekretua). Beraz, uholdeak sistema osoaren parte isolatu gisa ikasi beharrean, ibaiaren dinamikaren parte bezala ikasi beharra dago. Ibaia uraren zikloaren osagai dinamikoa da, eta denbora eta espazioaren arabera, aldaketak jasaten ditu arro hidrografikoan zehar. Horrela, ibaiaren hasieran ematen diren ekaitz handiek ibaiaren erdi- edo amaiera-aldean uholdeak sortu ditzakete (Martínez eta Gil, 2014).

Uraren zikloaren gaia bibliografian nahiko ugaria den arren, ibaien ikaskuntza-irakaskuntzarekin erlazionatutako lan gutxi daude. Ikasleekin ibaiaren modeloa ikasteko, gelan jarduerak egiteaz gain, garrantzitsua da landa praktikak egitea (Martínez eta Gil, 2014). Modeloa modu egokian ulertzeko, ikasleei jarduera-mota ezberdin ugari proposatu behar zaizkie, bai prozedura aldetik bai eta kontzeptuzko edukien aldetik ere. Horretaz gain, eskola-ikerketa txikiak proposatzea ere egokia da (Pedrinaci, 2013). Landa praktika hauen garrantzia handia bada ere, ikastetxeetako programa askotan ez dira barneratzen, beharbada hauek erabilgarriak izateko, plangintza, prestakuntza eta jarraikortasun handia eskatzen dutelako 
(Martínez eta Gil, 2014).

Oraindik, oraindik ere eskola askotan uholde-arriskuen inguruan lantzen diren edukiak oso murritzak dira. Unibertsitaterako sarrera frogaren eraginez, bigarren Batxilergoko irakasleek esfortzu handiena ikasleek selektibitateko ariketa motak ebazteko gai izatera bideratu ohi dira, eta ez hainbeste curriculumak eskatzen dituen edukiak eta konpetentziak lantzera. Izan ere, gurean ere badirudi "kanpoko ebaluazioek irakasle zein ikasleek curriculumaren edukiei ematen dieten garrantzia baldintzatzen dute, eta era berean, horrek eragina dauka irakaslearen irakaskuntza prozesuan alderdi metodologikoaren aldetik” (Oliva et al., 2016, 2. or). Selektibitateko galdera-mota hauetan, uholdeen arriskuak oso gainetik lantzen dira. Mota honetako galderak landuz ez dira curriculumean eskatzen diren “aurreikuspena, prebentzioa eta neurri zuzengarriak” lantzen. Uholdeak sistema konplexuago baten parte bezala ikastearen garrantzia azpimarratzen da (Martínez eta Gil, 2014). Eta selektibitateak (Unibertsitatera sartzeko hautaprobak), dudarik gabe, izugarri modelatzen du Batxilergoko bigarren ikasturtearen dinamika, besteak beste, hautaproba horretako ohiko galderak lantzen direlako behin eta berriro.

Hau guztia kontuan hartuta, lan honen helburu nagusia Batxilergoko bigarren mailako ikasleek uholde-arriskuak maila orokor zein pertsonalean nola hautematen dituzten aztertzea da. Gainera, uholdearriskuen inguruko trebakuntza jaso duten ikasleek beste ikasleekin alderatuz ezagutza- eta pertzepziomaila altuagoak ote dituzten aztertu da, bai eta arrisku-maila ezberdinetan bizi diren ikasleen jarrerak ere. Era berean, uholde-arriskuak modu sistemikoan lantzea ahalbidetzen duen proposamen didaktiko bat diseinatu da.

\section{Metodologia}

\subsection{Lagina}

Lagina zehazteko, laginketa metodo ez-ausazkoa burutu da. Metodo honetan, subjektuak ez dira zoriz aukeratzen, baizik eta beste irizpide batzuen arabera. Ikerketa honen kasuan, laginketa ezausazkoa izatearen arrazoiak ikerketako interes bereziak izan dira; hala nola, arrisku-maila ezberdineko ikastetxeak aukeratzeko nahia eta galdetegia egiteko bolondresak aurkitzeko zailtasuna.

Aukeratutako hiru ikastetxeak hauek izan dira: Gasteizen, Mendebaldea institutua, Bilbon, Kirikiño ikastola, eta Donostian, Antigua-Luberri institutua (Taula 1). Ikastetxe hauek duten uholde arrisku-maila ezberdina da. Mendebaldea BHI eta Kirikiño ikastola ez dira uholde-arrisku potentzial garrantzitsuko guneetan kokatzen, bai ordea, Antigua-Luberri institutua (I. eranskina). Hala ere, nahiz eta Mendebaldea eta Kirikiño ikastetxeak uholde-arrisku potentzial garrantzitsuko guneetan ez egon, haietatik oso gertu (1,5-2 km inguru), uholde-arrisku handiko guneak daude. 
Taula 1. Euskal Autonomia Erkidegoko hiru hiriburuetako ikastetxe ezberdinetan pasatu den galdetegi kopurua. Ikastetxe bakoitzeko ikasleek Lurraren eta Ingurumenaren Zientziak (LIZ) irakasgaia ikasten duten edo ez ere kontuan hartu da.

\begin{tabular}{llccc}
\hline & & LIZ ikasi & LIZ ez ikasi & Guztira \\
\hline Araba & Mendebaldea BHI & - & 23 & $\mathbf{2 3}$ \\
Bizkaia & Kirikiño ikastola & 9 & 42 & $\mathbf{5 1}$ \\
Gipuzkoa & Luberri BHI & 13 & 6 & $\mathbf{1 9}$ \\
Guztira & & $\mathbf{2 2}$ & $\mathbf{7 1}$ & $\mathbf{9 3}$ \\
\hline
\end{tabular}

Guztira 93 ikaslek parte hartu dute ikerketa honetan (Taula 1). Ikasleen batez besteko adina 17,4 (17-19 tartea) izan da eta ikasleen \% 54 mutilak izan ziren. Hala ere, ikerketa hau ez da zentratu generoen arteko ezberdintasunean.

Ikasleek duten formakuntza kontuan hartuta, bi talde bereiz daitezke. Batetik, Lurraren eta Ingurumenaren Zientziak irakasgaiaikasi duten 22 ikasle daude, eta bestetik, ikasi ez duten 71. Uholdearriskuen gaia bi ikastetxeetan Erein argitaletxeko liburuarekin (Lurraren eta Ingurumenaren Zientziak Batxilergoa 2) landu bada ere, batez ere II. eranskinean agertzen den selektibitate hautaprobako galdera ereduen antzekoak aztertuz landu da gaia.

\subsection{Datuak biltzeko tresnak eta datuen analisia}

Aipatu bezala, ikerketa honetan datuak biltzeko erabili den tresna galdetegia izan da. Jasotzen den informazioa kuantifikatzeko eta unibertsal bihurtzeko diseinatu da galdetegia eta bere helburua informazioa konparagarria izatea da. Elkarrizketarekin batera, ikerketetan gehien erabiltzen den tresna da, kostu txikikoa delako, parte-hartzaile gehiagora iristea ahalbidetzen duelako eta datuen analisia errazten duelako (Arribas, 2004).

Erabilitako galdetegia kuantitatiboa eta kualitatiboa izan da (III. eranskina). Galdetegiaren alde kuantitatiboaren neurketa egiteko, Likert eskala erabili da kasu gehienetan. Kasu horietan, parte-hartzaileek baieztapenekin duten adostasun-maila hiru mailatan banatu da: ados nago, ez nago seguru eta ez nago ados. Galdetegia behin baino ez da pasatu.

Erabilitako galdetegiaren lehen ataleko baieztapenak Bosschaart et al. (2013) eta Bosschaart et al. (2016) lanetatik egokitu dira. Bi lan hauek Herbehereetan egindako ikerketa batekoak dira, non 15 urteko ikasleen uholde-arriskuen ezagutza- eta pertzepzio-mailak neurtu ziren. Hori dela eta, 16 itemak Euskal Autonomia Erkideko egoerara moldatu behar izan dira. Lehenengo lau baieztapenen (B1-B5) helburua EAEn eta ikasleen ikastetxeko ingurunean egon daitezkeen uholdeen inguruko pertzepzioak neurtzea da. Bosgarren eta seigarren baieztapenen (B5-B6) helburua uholdeek izan ditzaketen ondorioen inguruko usteak ezagutzea da. 7-11. baieztapenek (B7-B11), uholdeek sortu ditzaketen zenbait eragileren inguruan ikasleek dituzten pertzepzioak neurtzea dute helburu. 12-14. baieztapenak (B12-B4) babes-neurrien ingurukoak dira, beraz, ikasleek sumatzen duten segurtasuna ezagutzea izan da hauen helburua. Azkenik, 
15. eta 16. baieztapenek ikasleek uholde-arriskuen aurrean duten beldurra neurtzeko balio izan dute Irudia 4).

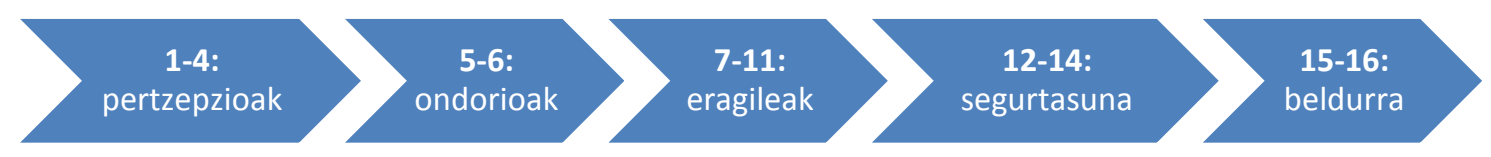

Irudia 4. Ikasleek betetako galdetegiaren 1. galderen item helburuak.

Bigarren atalaren helburua ikasleek haien ikastetxeko eskualdean dauden babes-neurriak eta uholdeek sortu ditzaketen eragileak ezagutzen ote dituzten testatzea izan da. Bigarren galdera hau aztertzeko, Cardak-en ( 2009) lanetik egokitutako kodifikazio-sistema erabili da. Horretarako, ikasleek egindako marrazkiak 4 kategoriatan banatu ziren: irudi ez-adierazgarria, irudi ez-ulergarria, irudi partziala eta irudi esanguratsua (Taula 2).

Taula 2. Uholdeak eragin ditzaketen eragileen eta uholdeetatik babesten gaituzten neurrien irudien analisirako erabili diren mailak, Cardak-etik (2009) egokitua.

\begin{tabular}{|c|c|c|}
\hline KATEGORIA & ULERMEN-MAILA & ESANAHIA \\
\hline 1 & Irudi ez-adierazgarria & $\begin{array}{l}\text { Ikasleek "ez dakit" erantzun dute edo ez dute ez } \\
\text { marrazkirik egin ez ezer idatzi (adibidez 5. A } \\
\text { irudian). }\end{array}$ \\
\hline 2 & Irudi ez-ulergarria & $\begin{array}{l}\text { Ikasleek marrazki oso sinpleak edo ulergaitzak egin } \\
\text { dituzte. Horien azalpenik eman gabe ez dira ulergarriak } \\
\text { (adibidea 5. B irudian). }\end{array}$ \\
\hline 3 & Irudi partziala & $\begin{array}{l}\text { Irudiak ulergarriak dira eta uholdeak eragin ditzaketen } \\
\text { eragileren bat edo uholdeengandik babesten gaituzten } \\
\text { neurriren bat ageri da (adibidea 5. C irudian). }\end{array}$ \\
\hline 4 & Irudi esanguratsua & $\begin{array}{l}\text { Irudi konpetenteenak eta ulergarrienak egin dituzte. } \\
\text { Uholdeen eragileak eta hauengandik babesten gaituzten } \\
\text { neurriak ageri dira (adibidea } \\
\text { 5. D irudian). }\end{array}$ \\
\hline
\end{tabular}

Erabili den galdetegiaren hirugarren atalean ikasleei hiru item aukeztu zitzaizkien, uholde-arriskua murrizteko har daitezkeen neurrien, arrisku-faktoreen eta giza- inpaktuaren ingurukoak, hurrenez hurren. Hauen helburua ikasleek uholde arriskuen inguruan duten ezagutza orokorra neurtzea izan da, ondoren diseinatu den sekuentzia didaktikoa ikasleen aurre-ezagutzetara hobeto egokitzeko. 


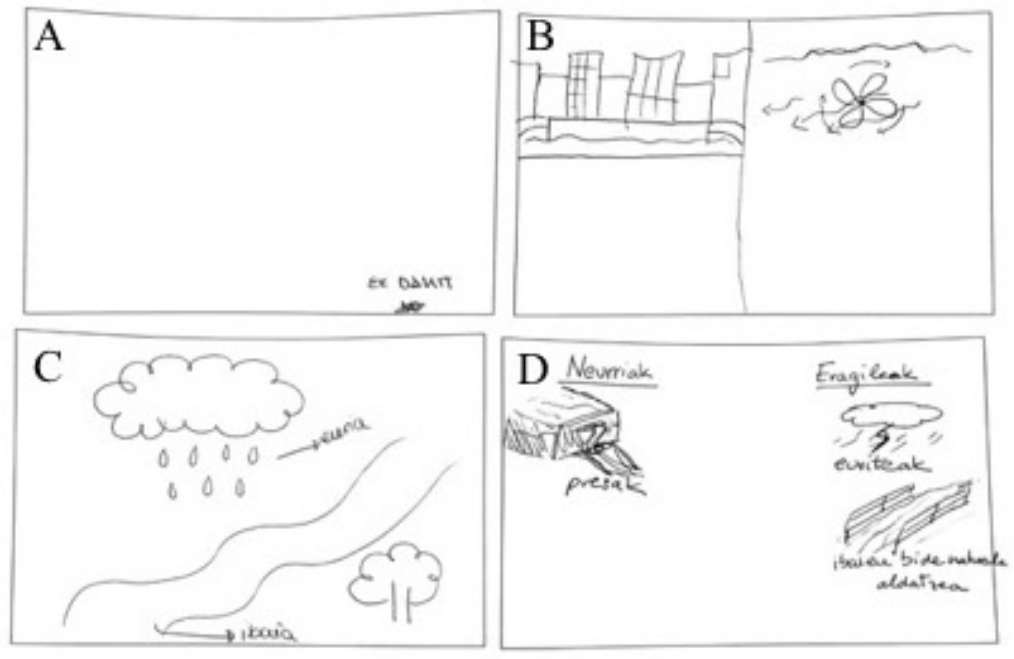

Irudia 5. A) irudi ez-adierazgarria (1. ulermen-mailaren adibidea), B) irudi ez-ulergarria (2. ulermenmailaren adibide), C) irudi partziala (3. ulermen-mailaren adibidea) eta D) irudi esanguratsua (4. ulermenmailaren adibidea).

Azkenik, galdetegiko laugarren atalak ikasleek uholdeei buruz jasotzen duten informazioari buruzko iritzia eta gaiaren inguruan duten interesa neurtzeko balio izan du.

Lurraren eta Ingurumenaren Zientziak irakasgaiak eta ikastetxeen arrisku-mailak ikasleen pertzepzio eta ezagutzetan duen eragina estatistikoki aztertzeko, $\chi$ karratuaren testa $(\alpha=0,05)$ erabili da.

\section{Emaitzak}

\subsection{Uholde-arriskuaren aurreko ikasleen pertzeptzioak}

Ikerketako emaitzak aztertuz, esan daiteke, orokorrean, uholde-arriskuen aurrean Batxilergoko bigarren mailako ikasleek duten pertzepzio-maila nahiko baxua dela (Taula 3).

Ikasleen \% 77-k Euskal Herrian uholdeak egon daitezkeela uste badu ere, ez du uste maiz gertatzen direnik edota eskola ingurunean eman daitezkeenik. Uholdeek sor ditzaketen ondorioei erreparatzen badiegu, aldiz, ikasleen erdiak baino gehiagok uste dute uholdeek kalte materialak eta pertsonalak eragin ditzaketela (3. Taulako 5. eta 6. baieztapenak). Uholdeak sortu ditzaketen eragileei dagokienez, \% 70-tik gorako erantzunekin, ikasleek ez dute uste haien ingurunean uraren gorakada handiak egon daitezkeenik edo iraganean egon zirenik, ezta haien ikastetxeak ur-ingurunetik gertuegi daudenik ere. Bestalde, ikasle kopuru berdinak erantzun du ados daudela eta ez daudela ados haien ikastetxeetatik gertu ekaitz handiak bizi izan dituztenaren baieztapenarekin (ikasleen \%38-ak kasu bakoitzean) (3. Taulako 8. baieztapena).

Uholdeen aurkako babes-neurriei dagokienez, ikasleek orokorrean asko ez dakitela ikusi da. Izan ere, egindako 3 baieztapenetan seguru ez daudela erantzun du gehiengoak. Azkenik, beldurraren sentsazioari dagokionez, Batxilergoko bigarren mailako ikasleek segurtasun-maila altua dutela agerikoa da. Izan ere, ikasleen \% 89-ak seguru sentitzen dela erantzun du. 
Taula 3. Galdetegiaren lehenengo ataleko itemen portzentajeak ( ikasle guztien erantzunak kontuan hartuta).

\begin{tabular}{|c|c|c|c|}
\hline & $\begin{array}{l}\text { Ados } \\
\text { nago }\end{array}$ & $\begin{array}{l}\text { Ez nago } \\
\text { seguru }\end{array}$ & $\begin{array}{c}\text { Ez nago } \\
\text { ados }\end{array}$ \\
\hline 1. Euskal Herrian uholdeak egon daitezkeela uste dut. & 77,42 & 15,05 & 7,53 \\
\hline 2. Euskal Herrian uholdeak maiz gertatzen direla uste dut. & 19,35 & 35,48 & 45,16 \\
\hline $\begin{array}{l}\text { 3. Nire eskola ingurunean uholdeak egon daitezkeela uste } \\
\text { dut. }\end{array}$ & 10,75 & 20,43 & 68,82 \\
\hline $\begin{array}{l}\text { 4. Nire eskola ingurunean uholdeak maiz gertatzen direla } \\
\text { uste dut. }\end{array}$ & 1,10 & 14,29 & 84,62 \\
\hline $\begin{array}{l}\text { 5. Nire eskola ingurunean uholdeak egonez gero, ondoko } \\
\text { eraikinetan edo/eta errepideetan kalte larriak egon } \\
\text { daitezkeela uste dut. }\end{array}$ & 57,61 & 30,43 & 11,96 \\
\hline $\begin{array}{l}\text { 6. Nire eskola ingurunean uholdeak egonez gero, kalte } \\
\text { pertsonalak egon daitezkeela uste dut. }\end{array}$ & 52,69 & 30,11 & 17,20 \\
\hline $\begin{array}{l}\text { 7. Nire eskola ingurunean uraren mailaren gorakada } \\
\text { handiak bizi izan ditut. }\end{array}$ & 3,26 & 11,96 & 84,78 \\
\hline 8. Nire eskola ingurunean ekaitz handiak bizi izan ditut. & 38,04 & 23,91 & 38,04 \\
\hline $\begin{array}{l}\text { 9. Nire eskola ur-inguruneetatik gertuegi dagoela iruditzen } \\
\text { zait. }\end{array}$ & 4,35 & 10,87 & 84,78 \\
\hline $\begin{array}{l}\text { 10. Familian noizbait entzun dut nire eskola ingurunean } \\
\text { uholdeak egon direla. }\end{array}$ & 18,28 & 8,60 & 73,12 \\
\hline $\begin{array}{l}\text { 11. Familian noizbait entzun dut nire eskola ingurunean } \\
\text { uraren mailaren gorakada altuak egon direla. }\end{array}$ & 18,28 & 10,75 & 70,97 \\
\hline $\begin{array}{l}\text { 12. Nire eskola ingurunea uholdeen aurrean ondo } \\
\text { babestuta dagoela uste dut. }\end{array}$ & 32,61 & 45,65 & 21,74 \\
\hline $\begin{array}{l}\text { 13. Nire eskola ingurunean uholdeen aurka dauden babes- } \\
\text { neurriek mantenu egokia dutela uste dut. }\end{array}$ & 17,20 & 68,82 & 13,98 \\
\hline $\begin{array}{l}\text { 14. Nire eskola ingurunean uholdeen aurkako babes-neurri } \\
\text { hobeak egon zitezkeela uste dut. }\end{array}$ & 41,94 & 46,24 & 11,83 \\
\hline $\begin{array}{l}\text { 15. Nire eskola ingurunean uholdeak egon daitezkeela } \\
\text { pentsatzeak beldur ematen dit. }\end{array}$ & 25,81 & 8,60 & 65,59 \\
\hline $\begin{array}{l}\text { 16. Ez naiz seguru sentitzen nire eskola ingurunean } \\
\text { uholdeak egon daitezkeela uste dudalako. }\end{array}$ & 1,08 & 9,68 & 89,25 \\
\hline
\end{tabular}

Kontuan hartzen baldin baditugu ikasleek Lurraren eta ingurumenaren zientziak irakasgaia lantzen duten edo ez, haien erantzunetan ezberdintasunak aurkitzen ditugu. Ezberdintasunik handiena pertzepzioetan aurkitzen dugu (Irudia 6), hipotesietan aurreikusi zen bezala, irakasgai hau ikasten duten ikasleek pertzepzio-maila handiagoa erakusten baitute. Gauza berdina gertatzen da uholdeen eragileen, 
babes-neurrien eta beldurraren inguruko baieztapenetan, non pertzepzio-maila altuagoa dutela ikusi den; ez, ordea, uholdeak eragin ditzaketen ondorioetan. Azken kasu honetan, Lurraren eta ingurumenaren zientziak ikasten ez duten ikasleen pertzepzio-maila handiagoa da. Hau ez dator guztiz bat Bosschaart et al.-en lanean (2013) lortutako emaitzekin. Izan ere, haiek adierazi zuten zenbat eta ezagutza handiagoa izan, orduan eta beldur gutxiago sentitzen zela, segurtasun sentsazio faltsua dela eta. Hala ere, irakasgai hau ikasi duten edo ikasi ez duten ikasleen pertzepzio-mailan antzematen diren ezberdintasun hauek guztiak ez dira estatistikoki esangarriak $\left(\chi^{2}, \mathrm{p}>0,05\right)$.

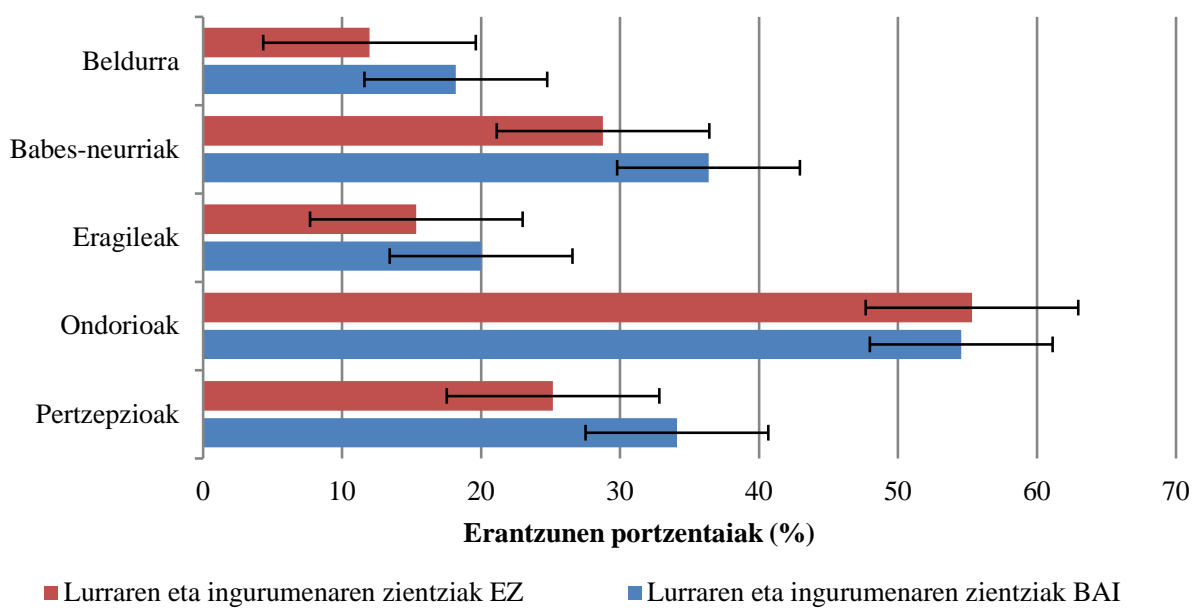

Irudia 6. Lurraren eta ingurumenaren zientziak ikasten eta ikasten ez duten ikasleen pertzepzioak ikertutako item-multzo bakoitzerako.

Bestalde, ikerketaren emaitzak ikastetxearen arrisku-mailaren arabera sailkatzen baldin baditugu, lortzen ditugun emaitzak esperotakoak dira. Kasu guztietan, beldurraren sentsazioan izan ezik, arrisku-maila altuagoa duen ikastetxeko ikasleek pertzepzio-maila altuagoak erakusten dituzte (Irudia 7). Hau guztiz bat dator Siegrst eta Gutscher-ek esandakoarekin (2006), izan ere, arrisku handiagoko eskualdeetan, ikasleak arriskuez kontzienteago dira. Hala ere, kasu honetan ere, ikusi izan da arrisku-mailaren araberako ezberdintasun hauek ez direla estatistikoki esanguratsuak $\left(\chi^{2}, \mathrm{p}>0,05\right)$.

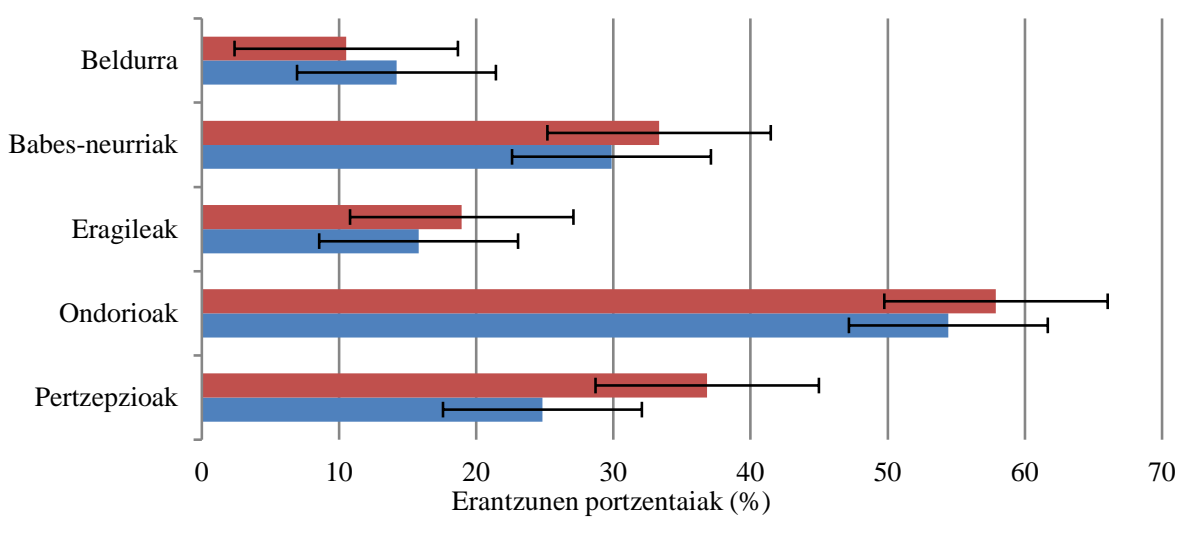

- Arrisku-maila altuko ikastetxea

— Arrisku-maila txikiko ikastetxea 
Irudia 7. Arrisku-maila altuko eta baxuko ikastetxeetako ikasleen pertzepzioak ikertutako item-multzo bakoitzerako.

\subsection{Uholde-eragile eta babes-neurrien inguruko ikasleen ezagutzak}

Hiru ikastetxeetan egindako galdetegietako irudien ulermen-maila Taula 4ean ageri da. Ikus daitekeen moduan, ikasleen gehiengoak egindako irudiak ez-ulergarriak edo partzialak izan dira, ikasleen \% 19ek ez zuen marrazkirik egin (irudi ez-adierazgarria), eta \% 12,9-ek bakarrik egin zuen marrazki esanguratsua. Hala ere, irudi esanguratsua egin zuten ikasleek, gehienez eragile eta babes-neurri bat edo bi irudikatu zituzten. Eragileen artean gehien irudikatu zena ekaitzak eta euria izan ziren, eta babes-neurri bezala, ibaien kanalizazioa.

Galdera honen kasuan, Lurraren eta ingurumenaren zientziak irakasgaia ikasi eta ikasi ez duten ikasleen eta arrisku-maila altua eta baxua duten ikastetxeetako ikasleen emaitzak parekoak izan ziren. Lortu diren irudi esanguratsuen proportzioa hain txikia izanik, ondorioztatu daiteke uholdeen aurkako babes-neurrien eta uholdeen eragileen inguruan ikasleek duten ezagutza-maila nahiko baxua dela. Galdera honetatik datu gehiago lortzea espero zen, baina baliozko irudi hain gutxi lortu zirenez, ezin izan da bestelako informaziorik atera.

Taula 4. Uholdeak eragin ditzaketen eragileen eta uholdeetatik babesten gaituzten neurrien inguruko marrazkien analisiaren emaitzak. Maiztasunak (N) eta ehunekoak (\%).

\begin{tabular}{|c|c|c|c|c|c|}
\hline Kategoria & $\begin{array}{c}\text { Ulermen- } \\
\text { maila }\end{array}$ & $\begin{array}{l}\text { Araba } \\
\text { n (\%) }\end{array}$ & $\begin{array}{c}\text { Bizkaia } \\
\text { n (\%) }\end{array}$ & $\begin{array}{c}\text { Gipuzkoa } \\
\text { n (\%) }\end{array}$ & $\begin{array}{c}\text { Guztira } \\
\text { n (\%) }\end{array}$ \\
\hline 1 & $\begin{array}{l}\text { Irudi ez- } \\
\text { adierazgarria }\end{array}$ & $2(\% 8,7)$ & $7(\% 13,7)$ & $9(\% 47,4)$ & $18(\% 19,4)$ \\
\hline 2 & Irudi ez-ulergarria & $8(\% 34,8)$ & $20(\% 39,2)$ & $3(\% 15,8)$ & $31(\% 33,3)$ \\
\hline 3 & Irudi partziala & $12(\% 52,2)$ & $17(\% 33,3)$ & $3(\% 15,8)$ & $32(\% 34,4)$ \\
\hline 4 & Irudi esanguratsua & $1(\% 4,3)$ & $7(\% 13,7)$ & $4(\% 21,1)$ & $12(\% 12,9)$ \\
\hline \multicolumn{2}{|c|}{ Guztira } & 23 & 51 & 19 & 93 \\
\hline
\end{tabular}

\subsection{Uholde-arriskuen inguruko ikasleen ezagutza orokorra}

Ikerketan erabilitako galdetegiaren hirugarren galderan, ikasleei uholde-arriskuak murrizteko hartu beharreko neurriei buruz, uholdeak sortu ditzaketen arrisku-faktoreei buruz eta giza jarduerek uholdearriskuengan izan dezaketen eraginei buruz galdetu zitzaien. Erantzun anitzeko galderak egin zitzaizkien, uholde-arriskuen inguruan zekitena jaso ahal izateko. Emaitzei erreparatzen badiegu, ez zen ikasle bat ere egon erantzun guztiak markatu zituena. Bostgarren taulan galdetegiko 3. ataleko item bakoitzean lortutako erantzun kopuruak ageri dira.

Uholde-arriskua murrizteko har daitezkeen neurriei dagokienez, hau da, lehenengo itemari dagokionez, gehien markatutako erantzuna uholdeak pairatzeko joera duten eremuetan gehiago ez eraikitzea izan zen. Bestalde, ikasleek gutxien markatu zuten erantzuna uholde lautadak errespetatzea eta berreskuratzea izan zen (Taula 5).

Uholdeak eragin ditzaketen arrisku-faktoreen galderari dagokionez (bigarren azpi-galdera), hauek izan ziren ikasleek emandako erantzun kopuruaren ordenak (Taula 5): gehien markatu zena (erantzunen \% 33,5) aldaketa klimatikoa izan zen, jarraian, ibaien sorburuaren eta itsasoaren arteko distantzia laburra, topografia 
aldapatsua eta eskualdeko klimatologia izan ziren, eta azkenik, ikasleen \% 12,5-ek bakarrik markatu zuen ibai bazter eta mendietan landaretza urria egotea arrisku-faktorea izan zitekeela.

Taula 5. Galdetegiko erantzun anitzeko galderan (3. atala) lortutako erantzun kopuruak eta erantzunen proportzioak.

\begin{tabular}{|c|c|c|c|}
\hline Azpi-galderak & Erantzunak & n (\%) & N guztira \\
\hline \multirow{4}{*}{ 1. galdera } & $\mathrm{a}$ & $42(26,9)$ & \multirow{4}{*}{156} \\
\hline & $\mathrm{b}$ & $39(25,0)$ & \\
\hline & C & $31(19,9)^{*}$ & \\
\hline & $\mathrm{d}$ & $44(28,2) * *$ & \\
\hline \multirow{5}{*}{ 2. galdera } & $\mathrm{a}$ & $24(12,6) *$ & \multirow{5}{*}{191} \\
\hline & $\mathrm{b}$ & $52(27,2)$ & \\
\hline & c & $26(13,6)$ & \\
\hline & $\mathrm{d}$ & $25(13,1)$ & \\
\hline & e & $64(33,5)^{* *}$ & \\
\hline \multirow{4}{*}{ 3. galdera } & $\mathrm{a}$ & $26(16,5)^{*}$ & \multirow{4}{*}{158} \\
\hline & $\mathrm{b}$ & $38(24,0)$ & \\
\hline & c & $57(36,1)^{* *}$ & \\
\hline & $\mathrm{d}$ & $37(23,4)$ & \\
\hline
\end{tabular}

Azkenik, hirugarren itemean giza jarduerek uholde-arriskuengan izan zitzaketen inpaktuei buruz galdetu zitzaien ikasleei. Bertan, ikasleek gehien markatu zuten erantzuna behar ez den tokietan eraikinak eta errepideak eraiki izan zen. Bestetik, gutxien markatutako erantzuna uraldietako ubideak bete izan zen.

Wagner-ek (2007) esan bezala, emaitza hauetatik ondorioztatu daiteke, ikasleek dituzten ezagutzen parte handi bat esperientzia pertsonaletik edota komunikabideetatik jasotako informaziotik datorrela. Izan ere, gehien markatutako erantzuna aldaketa klimatikoa izan zen, komunikabideetan eta iragarkietan behin eta berriz aipatzen den gaia, alegia. Bestetik, behar ez den tokian eraikitzea izan zen beste erantzun arrunta. Kasu honetan ere, ohikoa da komunikabideetan entzutea eraikuntzak edo errepideak kaltetuak izan direla arrisku-eremuetatik gertu kokatuta zeudelako. Bestetik, ikusita ikasleek uholde-arriskuen inguruan dituzten ezagutzak nahiko txikiak direla, esan dezakegu orain arte gaia lantzeko erabili duten metodologia, hau da, selektibitateko ariketamotak lantzea, ez dela eraginkorregia izan, Oliva et al.-ek (2016) aurreikusi bezala. Hori horrela, artikulu honen amaieran ezagutza hauek handitzeko proposamen didaktiko bat aurkezten da.

\subsection{Uholde-arriskuen inguruko ikasleen interesa}

Galdetegiaren azken atalaren helburua ikasleek gaiaren inguruan duten interesa aztertzea izan da. Guztira, ikasleen \% 71-ek uste dute ez dutela informazio nahikoa jasotzen, hala ere, \% 61-ek du adierazi informazio gehiago jasotzea gustatuko litzaiokela. Horrek adierazten du, nahiz eta ikasleek uste duten informazio nahikoa jasotzen ez dutela, orokorrean interes txikia dutela uholde-arriskuen gaian.

Ikastetxeen arrisku-mailaren araberako sailkapena egiten badugu, arrisku-maila baxuko ikastetxeko ikasleak dira gehien uste dutenak informazio nahikorik jasotzen ez dutela (\% 80); arrisku-maila altuko ikastetxeetako ikasleen \% 52-arekin alderatuz. Horretaz gain, arrisku-maila altuko ikastetxeetako ikasleen \% 
63ari uholde-arriskuen inguruko informazio gehiago jasotzea gustatuko litzaioke; arrisku-maila baxuko ikastetxeetako ikasleen kasuan, aldiz, \% 59-ek baino ez dute informazio gehiago jaso nahi.

Lurraren eta ingurumenaren zientziak irakasgaia ikasten eta ikasten ez duten ikasleak kontuan hartzen baditugu, irakasgai hau ikasten duten ikasleek ikasten ez dutenekin konparatuz, informazio gehiago jasotzeko nahi handiagoa adierazi dute. Era berean, irakasgaia ikasten ez duten ikasleen \% 79-ek uste dute ez dutela informazio nahikorik jasotzen eskolan zein eskolatik kanpo.

\section{Esku-hartze didaktikoaren proposamena}

Jarraian proposatzen den unitate didaktikoa Batxilergoko bigarren mailako Lurraren eta ingurumenaren zientziak irakasgaian erabiltzeko diseinatu da. Lehen aipatu bezala, uholde-arriskuak geroz eta maiztasun handiagoz sufritzen ditugu maila lokal zein globalean (Olcina, 2009). Arrisku hauen kudeaketa gizarte osoaren ardura da, ez bakarrik administrazioena (Pahl-Wostl, 2006). Hori dela eta, eta arrisku hauen aurrean prest egon ahal izateko, uholde-arriskuaren kudeaketa egokia egiten ikastea ezinbestekoa bilakatu da. Ikasketa-prozesu horretan eskolek berebiziko papera jokatzen dute, ikasleen pertzepzioak eta ezagutzak handitzeko aukera ematen dutelako (Shaw et al., 2004), eta hori da; hain zuzen ere, proposatutako esku-hartze didaktiko honen helburua.

Helburu hau lortu nahian, 12 jardueratako sekuentzia didaktikoa diseinatu da; non ikasleek, irakasleak proposatutako baliabide eta galderen bitartez, euren ezagutzak eraikitzen joango direen pausuz-pusu. Proposatzen diren jardueren bidez, ikasleek behaketak egin, euren buruei galderak planteatu, baliabide digitalak erabili eta aztertu, ikerketa txikiak planifikatu, datuak bildu, aztertu eta interpretatu, galderak, azalpenak eta hipotesiak proposatu, ikasitakoa komunikatu eta beste ikaskideekin batera ikasiko dute. Hau da, azken finean, indagazioaren bidezko zientziaren hezkuntzak lortu nahi duena (Camacho et al., 2008).

Ikaskuntza-irakaskuntza prozesuan indagazioaren erabilera ezinbestekoa bihurtu da, izan ere, etengabe aldatzen ari den mundu batean bizi garenez, ikasleek eguneroko bizitzako arazo eta problematikei aurre egiteko beharrezkoak izango dituzten estrategiak ikasi beharko dituzte. Hori dela eta, ikerketan oinarritzen den ikaskuntza-metodologiak indarra hartu du. Azken finean, indagazioaren bidezko ikaskuntzaren muina postulatu honen bidez defini genezake: “esadazu eta ahaztuko zait, erakutsidazu eta gogoratuko dut, inbolukra nazazu eta ulertuko dut” (Pérez-Villalobos et al., 2017).

Metodologia honen bidez, ikasleen pentsamendu kritikoa garatzea bilatzen da eta, bide batez ikasgela mailan pentsamendu sakona lantzea. Hau da, kontzeptualki aberatsa den, modu koherentean antolatuta dagoen eta jakin nahia pizten duen pentsamendua, hain zuzen ere (López, 2012). Hori dela eta, zientzia arloarekin erlazionatutako eta gizartean sortzen diren eztabaidak eta iritzi ezberdintasunak oso erabiliak dira hezkuntzan. Izan ere, gai hauek ikasleen jakinmina piztu dezakete, eta horrela, haien iritzi kritikoa emateko beharra sortzen da. Eztabaida sozio-zientifikoak zientziaren eta gizartearen arteko harreman konplexutik sortzen diren arazoak dira, eta normalean, gizartearen, zientzialarien, komunikabideen, administrazioaren eta enpresen arteko iritzi ezberdintasunagatik sortzen dira (Díez eta Jiménez-Liso, 2012). Unitate didaktiko honetan eztabaida sortu dezaketen gaien inguruan modu kritikoan hausnartzeari eta datuetan oinarritutako argudiaketari garrantzia eman zaio. Izan ere, ikasleei azken urteetan eztabai sortu duten gaien inguruan hausnartzeko eskatzen zaie. 
Zehazki, sekuentzia honen hasieran ikasleei herriko ibaien inguruan dakitena aztertuko da eta ibaiaren profilari eta mantentze lanei buruzko informazioa irakurriko dute. Ondoren, ibaiari buruzko marrazki bat egingo dute haren sorburua, isurtzen den itsasoa eta abarrak zehaztuz. Hirugarren jardueran norberak bere herriko errekaren ezagumenduan sakonduko du. Jarraian, laugarren jardueran, ikasle bakoitzak ibaiaren definizio zehatza emango du. Bostgarren jardueran uholdeak fenomeno naturalak direla eta gure lurraldean gertatzeko arriskua dagoela ikusiko dute zenbait bideo eta argazkien bitartez. Seigarrenean norberaren herrian uholdearriskua nolakoa den aztertuko dute. Jarraian uholde-arriskuari dagokionez Euskal Herriko egungo egoera identifikatuko dute, uholdeen kausak bai eta hartu beharreko neurriak ere. Bederatzigarren jardueran Aldaketa klimatikoaren eragina aztertuko dute. Ondoren, uholde-arriskuaren prebentzioan dauden neurri estrukturalak zein neurri ez estrukturalak ezagutuko eta aztertuko dituzte. Horiekin batera uholdeak aurresateko dauden baliabideak ezagutuko dituzte. Amaitzeko bigarren jardueran ikasle bakoitzak eginiko ibaiaren marrazkia osatuko edota zuzenduko dute sekuentzian zehar ikasitakoa baliatuz.

\subsection{Unitate didaktikoaren helburuak}

Honako hauek dira proposatutako jarduera sekuentziaren bidez lortu nahi diren helburu didaktikoak:

- Uholde-arriskuak aurreikusteko, arriskuak aurreikusteko eta horien aurkako neurri zuzentzaileak proposatzeko gaitasuna lortzea.

- Uholdeak sor ditzaketen arrisku-faktoreak identifikatzea eta horien aurrean modu arduratsuan jokatzea.

- Gizabanako bakoitzak ingurugiroan eragin ditzakeen ondorioez jabetzea, eta ondorio horiek minimizatzeko, nork bere erabakiak hartu eta erantzukizunak onartzea.

- Ikerketa txikiak egiten ikastea, eta ikerketetan lortutako emaitzak interpretatzen jakitea.

- Uholde-arriskuek gizartean sor ditzaketen eztabaidez jabetzea eta horien aurrean modu kritikoan jokatzen jakitea.

- Ideiak eta konponbideak sortzea eta egungo egoera hobetzeko proposamenak egitea.

\subsection{Jarduera sekuentziaren antolaketa}

Aipatu bezala, unitate didaktiko hau 10 jardueratan banatzen da, non baliabide digitalen presentzia nabarmentzekoa den. Ikasleak taldekatzeko moduari begira, lan egiteko modu ezberdinak landu nahi izan dira (bakarka, bikoteka, talde txikietan edota talde handitan). Unitatearen parterik handiena gelan egingo den arren, irteera bat proposatu da, non ikasleek haien herritik gertu dagoen ibai batera joateko aukera izango duten.

\subsection{Sekuentzia didaktikoak euskal curriculumarekin duen lotura}

Unitate didaktikoan zehar, Euskal Curriculumak (236/2015 Dekretua) zehazten dituen oinarrizko konpetentzia hauek lantzen dira, ondorengo jardueren bidez:

A. Oinarrizko zehar konpetentziak:

- ZK1. Hitzezko eta hitzik gabeko komunikaziorako eta komunikazio digitalerako konpetentzia: 2J, 3J, 4J, 5J, 6J, 7J, 10J, 11J, 12J, 13J 
- ZK2. Ikasten eta pentsatzen ikasteko konpetentzia: 1J, 3J, 4J, 6J, 7J, 8J, 9J, 10J, 11J, 12J

- ZK3. Elkarbizitzarako konpetentzia: 7J, 11J, 12J, 13J

- ZK4. Ekimenerako eta espiritu ekintzailerako konpetentzia: 3J, 7J, 11J, 12J

- ZK5. Norbera izaten ikasteko konpetentzia: 6J, 7J, 9J, 11J

B. Oinarrizko diziplina barruko konpetentziak:

- DBK1. Hizkuntza- eta literatura-komunikaziorako konpetentzia: 2J, 3J, 4J, 5J, 6J, 7J, 10J, 11J, 12J, $13 \mathrm{~J}$

- DBK2. Zientziarako konpetentzia: 1J, 2J, 3J, 4J, 5J, 6J, 7J, 8J, 9J, 10J, 11J, 12J

- DBK3. Teknologiarako konpetentzia: 1J, 3J, 5J, 6J, 7J, 9J, 11J

- DBK4. Konpetentzia sozial eta zibikoa: 7J, 8J, 9J

- DBK5. Arterako konpetentzia: 2J, 10J

- DBK6. Konpetentzia motorra: $11 \mathrm{~J}$

\subsection{Sekuentzia didaktikoaren ebaluazioa}

Unitate didaktikoaren ebaluazioa egin ahal izateko, ondorengo ebaluazio-irizpide adierazleak eta tresnak erabiltzea proposatzen da:

A. Ebaluazio-irizpide adierazleak:

- Ariketak, ikerketak eta debateak egiteko informazio nahikoa, fidagarria eta zehatza lortzen du.

- Informazio argia eta zehatza aurkezten du.

- Lana modu kooperatiboan egiten du, taldekideen lana eta iritzia errespetatuz.

- Ahozko azalpenetan eta idatzizko txostenetan argitasuna, ordena eta zehaztasuna adierazten du.

B. Ebaluazio tresnak:

- Eguneroko lana, ikasleen koadernoa behatuz.

- Ibaiaren egoeraren inguruan taldeka egindako ikerketaren txostena.

- Debatea, errubrikaren bidez.

\subsection{Sekuentzia didaktikoa: ZURE HERRIAN UHOLDE-ARRISKURIK BADAGO?}

\subsubsection{Sarrera}

Ura beharrezkoa dugun eta etengabe erabiltzen dugun baliabide naturala da. Izaki bizidunontzako ezinbestekoa da, izan ere, naturan gertatzen diren prozesu biologiko, kimiko eta fisiko gehienen parte da. Ura guztiona da eta guztion ardura da bere zaintzan parte hartzea. Ura planetako baliabide naturalik preziatuenetarikoa izanik, bere banaketa ekitatiboa eta ustiaketa jasangarria XXI. mendeko erronkarik handienetakoa da. Azken urteetan emandako populazioaren hazkuntza azkarrak uraren gehiegizko ustiaketa ekarri du. Alde batetik, ura beharrezkoa dugu edateko, baina, uraren erabilerarik handiena, \%70 inguru, nekazaritzarako erabiltzen da. Gehiegizko ustiapen honek baliabide hidrikoen gaineko presioa zeharo handitu du, uraren ziklo naturala eraldatuz.

Ibaiak uraren zikloko osagai dinamikoak dira, denboran eta espazioan aldaketa ugari pairatzen dituztenak. Gizakiok ibaiengan sortzen dugun presioa oso handia da eta ingurugiroan arriskuak sor ditzaketen inpaktuak 
eragiten ditugu. Inpaktu hauek mehatxagarriak dira bai ibai ekosistemetarako, bai eta bertan bizi diren espezieentzako ere. Sortzen ditugun inpaktuen eraginez, guretzako eta beste espezieentzako kaltegarriak diren arriskuak sortzen dira. Arrisku natural horien artean, uholdeak dira gaur egun gure eskualdean kalterik handienak eragiten dituzten arrisku naturalak. Sortzen dituzten kalte hauek materialak izateaz gain, zeintzuek ekonomiaren aldetik gastu izugarri handiak suposatzen duten, giza-bizitzaren galeran ere kalteak sortzen dituzte.

Hau guztia kontuan hartuta, azken hamarkadetan, uholde-arriskuen kudeaketarako plan ezberdinak sortu dira, maila lokal zein globalean. Kudeaketa hau ezinbestekoa da etorkizun hurbil zein urrunean gertatu daitezkeen kalteak aurresateko, prebenitzeko edota kalteak konpontzeko. Kudeaketa egoki hau guztion ardura da, beraz, zer egin dezakegun guk geroz eta larriagoa bihurtzen ari den arazo honi konponbidea emateko?

\subsubsection{Jarduera. Ibaiak ezagutuz}

Zer dakizu ibaien inguruan? Jarri bikoteka eta bisitatu jarraian proposatzen zaizuen esteka. Bertan ibaien atalei, ibaiaren profilari, ibaiaren egoera ezberdinei eta mantentze-lanei buruzko informazioa irakurri ahal izango duzu:

\section{http://www.uragentzia.euskadi.eus/ura/index_euskera.html}

Irakurri arretaz informazio guztia, eta idatzi itzazue koadernoan berriak diren termino edo prozesu guztiak, gaia ondo ulertzeko ezinbestekoak izango baitira.

\subsubsection{Jarduera. Ibaia marraztuz}

Ezagutzen al duzu zure herriko ibaia? Marraztu ezazu zure herri ondotik pasatzen den ibaia/erreka, irudian honako hauek irudikatuz eta izendatuz:

o Non sortzen den (iturburua)

o Nora isurtzen dituen urak

o Zure herriak nondik jasotzen dituen urak (urtegia,...)

o Zein neurri dauden zure herrian egon daitezkeen uholde-arriskuak minimizatzeko

o Uholdeak sortu ditzaketen eragileak

o $\quad$. .

Saiatu zaitez ahalik eta zehaztasun handienarekin marrazten, baina ez kezkatu gauza guztiak ez badakizkizu, unitatean zehar landuko ditugun gauzak izango baitira.

\subsubsection{Jarduera. Zure herritik gertu dagoen ibaia ezagutuz}

Lehenengo jardueran ibaiak aztertu baditugu ere, modu orokorrean izan da. Goazen orain gure herriko ibai/erreka apur bat gehiago ezagutzera! Erantzun itzazu ondorengo galderei (beharbada interneten bilatu beharko duzu informazioa):

o Nola deitzen da zure herritik pasatzen den ibaia?

o Ibai nagusia da edo beste ibai handiago baten ibaiadarra da? Zeinena? 
o Zein arro hidrografikori dagokio?

o Nondik datoz ibaira isurtzen diren urak (mendizerra, ...)?

o Nora isurtzen du ura?

Jarraian, zure ibaiaz gain, Euskal Herriko beste ibaiak ezagutzeko aukera emango dizun aplikazio bat erabiliko dugu. GEOS aplikazioaren bidez (app Android, iPhone edota iPad-erako), Euskal Herriko ibaien kokapena ikasiko duzu. Nahi izanez gero, aplikazioaren bidez, mendiak, mendikateak, lakuak, herriak, hondartzak eta abar ere ikasi ditzakezu. Deskargatu aplikazioa zure mugikorrean eta hasi jolasten!

\subsubsection{Jarduera. Ibaia definitzen}

Behin ibaiak apur bat hobeto ezagutzen dituzula (ibaien atalak, funtzionamendua, kokapena, ...), saia zaitez ibaiaren definizio ahalik eta osatuena ematen. Ez ahaztu ibaia sistema dinamiko bat dela eta bertan osagai askok elkarrekiten dutela!

\subsubsection{Jarduera. Uholdeak fenomeno naturalak dira}

Uholdeak jatorri naturala duten fenomeno naturalak dira. Naturan berez gertatzen diren arren, giza inpaktuek berez sor ditzaketen kalteak asko handiagotzen dituzte. Aldaketa klimatikoaren eraginez, uholdeak maizago eta intentsitate handiagoaz gertatuko direla aurresan dute adituek. Baina, gure eskualdean uholdeak egoteko arriskua al dago?

Gure ingurunean uholdeak gertatzeko arriskua ez dagoela pentsatzen dutenentzako, gurean gertatu izan diren uholde ezberdinen bideo eta argazkiak dituzue hemen eskuragarri:

https://www.berria.eus/paperekoa/2048/008/001/2019-07-09/zidakos-ibaiak-euriteekin-gainezka-egin-dueta-kalte-handiak-egin-ditu-tafallan.htm

http://www.eitb.eus/eu/eguraldia/argazkiak/osoa/5527643/argazkiagaleria-uholdeak-nafarroan-2018koapirilean-/

http://www.eitb.eus/es/noticias/sociedad/detalle/1404442/inundaciones-bilbao-1983-30-aniversario-26agosto-2013-/

https://www.eitb.eus/eu/albisteak/gizartea/osoa/6669001/tanta-hotza-espainian-orihuelan-seigarrenhildakoa-topatu-dute-2019-irailak-14/ https://www.eitb.eus/eu/telebista/programak/egunon-euskadi/bideoak/osoa/6784232/bideoa-unai-pascualbc3ko-ikertzailea-euskal-herriko-uholde-arriskuez/

\subsubsection{Jarduera. Uholde-arriskuak identifikatzen}

Behin gure eskualdean uholdeak pairatzeko aukera dagoela ikusita, goazen uholde-arriskua zer den ikustera.

Arriskua fenomeno natural bat gertatzeko probabilitatea bezala definitu dezakegu, indibiduo batek arriskua sufritzeko duen probabilitatea hain zuzen. Arriskua definitzerako orduan, termino hauek hartu behar dira kontuan: arriskugarritasuna, zaurgarritasuna eta esposizioa. Izan ere, hiru faktore hauen elkarrekintzak eragiten dute arriskua. 
Hau kontuan izanda, zure herrian uholde arrisku-maila nolakoa dela uste duzu? Txikia ala handia? Sartu zaitez ondorengo web orrialdean eta begiratu zehazki nolakoa den arrisku-maila:

http://www.uragentzia.euskadi.net/appcont/gisura/

\subsubsection{Jarduera. Euskal Herriko egoera identifikatzen. Uholdeen kausak eta hartu beharreko neurriak}

Irakurri ezazu Argia aldizkarian 2016ko martxoan Arturo Elosegiri, EHUko Ibaien Ekologia taldeko ikertzailea eta ekologia katedradunari, egindako elkarrizketa: "Bizkai, Gipuzkoa eta Nafarroa iparraldeko ibai denak dauzkagu desbideratuta, eta ezin dute ongi funtzionatu"

http://www.argia.eus/argia-astekaria/2501/arturo-elosegi

Zein esango zenuke direla uholdeak sortzen dituen kausa nagusiak? Eta prebentzio-neurriak? Bete ezazu ondorengo taula (Taula 7). Informazio gehiago jasotzeko, erabili ordenagailuak.

Taula 7. Uholdeen arrisku faktore nagusiak eta horren aurrean hartu beharreko neurriak.

\section{Arrisku-faktoreak}

\section{Neurriak (prebentzioa)}

Erantzun ondorengo galdera hauei, lehenengo 4-5 pertsonatako taldeetan, eta ondoren, talde osoan.

o Uste al duzu zilegi dela ibaien emariak desbideratzea, eraldatzea, presak eraikitzea, ... gizakion eguneroko beharrizanak asetzeko?

o Testuan aipatzen da Andoainen 12 metroko Inturiako presa bota zenean biztanle asko kontra jarri zirela, nahiz eta presa horrek aspalditik ezertarako balio ez zuen. Zergatik uste duzu gizarteak bere ongizatea bilatzen duela beti ingurugiroan eman daitezkeen kalteak kontuan hartu gabe?

o Zer egin genezake egoera honi irtenbidea emateko eta gizartea naturako kontuetan konpromiso handiagoa hartzeko?

\subsubsection{Jarduera. Klima aldaketaren eragina aztertzen}

Irakurri ezazu Argian publikatutako ondorengo artikulua: "Europarren \%86k pairatuko ditu uholdeen kalteak klima aldaketaren ondorioz, kasurik arinenean":

http://www.argia.eus/albistea/europarren-86k-pairatuko-lituzke-uholdeen-kalteak-klima-aldaketarenondorioz-kasurik-arinenean

Bestalde, aztertu ezazu Berrian argitaratutako beste hau ere, 2050 urteko egoera aurreikusteko Ameriketako Estatu Batuetako Climate Central ikerketa zentroak egin duen modeloa:

https://www.berria.eus/albisteak/173119/euskal-herriko-itsasadarren-inguruan-milaka-lagun-bizi-direnlurrak-hartuko-ditu-urak-2050erako.htm 
Uste al duzu, beraz, klima aldaketak eragina duela uholdeak gertatzeko arriskuan? Azaldu ezazu zure erantzuna.

\subsubsection{Jarduera. Uholde arriskuen prebentzioa}

Uholdeak EAEn historian zehar kalterik handienak eragin dituzten arrisku naturalak izanik, plangintza hidrologikoaren helburu garrantzitsuenetariko bat hauen arriskua gutxitzea izan da. Plangintza honen barruan, estrukturalak ez diren neurriak neurri estrukturalekin konbinatu dira.

Bila ezazu zer diren uholdeen aurka hartu daitezkeen neurri estruktural eta ez-estrukturalak eta idatz itzazu haien definizioak koadernoan. Hemen lortu dezakezu informazioa:

https://www.boe.es/buscar/doc.php?id=BOE-A-2010-11184 (uztailaren 9ko 903/2010 Errege Dekretua).

o Neurri estrukturalak:

o Neurri ez-estrukturalak:

Ezagutzen al dituzu udal, autonomia edota estatu-mailan uholdeak aurresateko edota prebenitzeko dauden planak? Irakurri ondorengo estekan agertzen den informazioa (72. orrialdetik aurrera) eta egizu eskema bat ideia garrantzitsuenak jasoz.

http://www.uragentzia.euskadi.eus/contenidos/informacion/docu_plan_gestion_riesgo_inund/eu_def/adj untos/20151223/PGRI_DHC_ORIENTAL_2016_ED\%2020_2016_eu.pdf

\subsubsection{Jarduera. Ibaiaren marrazkia osatuz}

Har ezazu 2. jardueran egindako ibaiaren marrazkia. Orain arte ikasitakoarekin, saia zaitez marrazkia ahalik eta gehiago osatzen, eta aurretik akatsen bat egonez gero, hori zuzentzen.

\section{Eztabaida}

Uholde-arriskuen inguruan, oro har, ikastetxeetan lantzen diren edukiak nahiko eskasak dira eta ez diete ikasleei fenomenoa bere osotasunean ulertzen ahalbidetzen. Lan honetan burutu den ikerketan ikusi den bezala, ikastetxe askotan Unibertsitaterako sarrera frogan agertzen diren ariketak eginez lantzen da gai hau, baina emaitzek erakutsi duten moduan, eta Oliva et al.-ek (2016) berresten duen moduan, hori ez da nahikoa ikasleen uholde-arriskuen inguruko ezagutza nahikoa lortzeko. Uholde-arriskuen gaia lantzeko ariketa-mota hauek erabiliz, euskal curriculumak zehazten duen "arrisku klimatikoak: iragarpena, prebentzioa eta neurri zuzentzaileak” ez dira osotasunean lantzen. Izan ere, hauek gehien bat uholdeak sortzen dituzten kausetan zentratzen dira. Honen aurrean, Martínez-ek eta Gil-ek (2014) uholdeak sistema konplexuago baten parte bezala ikastea ezinbestekoa dela proposatzen dute. Hori dela eta, lan honetan diseinatutako unitate didaktikoak uholdeak ibai-sistemaren dinamikaren parte bezala lantzea helburu izan du, eta honek, modu sakonagoan ulertzeko aukera ematen du.

Lan honetan proposatzen den unitate didaktikoarekin, Bach-ek eta Márquez-ek (2017) azaltzen dituzten zientziaren bi helburu nagusiak betetzen dira. Alde batetik, sistema bere osotasunean ulertzen saiatzen da, bertan gertatzen diren prozesuak eta elkarrekintzak ulertuz, hala nola, ibaiaren funtzionamendua, ibaian egon daitezkeen eraldaketak eta giza inpaktuak sor ditzakeen eraginak aztertuz. Bestetik, ikasleen artean jarrera 
jasangarriak bultzatzen saiatzen da. Izan ere, lan honetan proposatutako jarduera gehienetan, edukiak lantzeaz gain, Siegrist-ek eta Gutscher-ek (2006) proposatzen zuten ikasleen hausnarketa ere bultzatzen da. Hala ere, hausnarketa bultzatzeaz gain, lan horretan ikasleak arrisku pertsonalaren gutxitzea dakartzaten ekintzak egitera bultzatu behar direla aipatzen da, eta hori, proposamen didaktiko honetan falta den baina egon beharko litzatekeen aspektu bat da.

Zientziaren didaktika arloan, behin eta berriz hitz egiten da alfabetatze zientifikoaz. Hori horrela, alfabetatze hau lortu nahian, ikasleek ikasten dituzten ezagutzak praktikan jartzea bilatu da lan honetan, eguneroko bizitzako arazoak planteatuz eta horiei konponbidea bilatzen saiatuz. Aguerri eta Bravo-Torrijak (2017) esan bezala, ezagutza hauek erabakiak hartzeko balio behar dutenez, ikasleei egunerokotasuneko problematikak erakutsi zaizkie, gai izan daitezen hauek analizatzeko, datuak interpretatzeko eta ondorioak bilatzeko, beti ere modu kritikoan jokatuz.

Proposamen didaktiko hau diseinatu zenean, bibliografian oinarritutako lanak kontuan hartu ziren, bai edukien aldetik eta bai metodologiaren aldetik ere. Hala ere, lan honek izaera berritzailea dauka, izan ere, planteatutako jarduerak Euskal Autonomia Erkidegoko herri eta ibaietarako espreski diseinatuta daude. Modu honetan, ikasleei haien herrietatik gertuko ibaiak ezagutzeko aukera ematen zaie, ezagutza lokala bultzatuz. Hori da, Aguerrik eta Bravo-Torrijak (2017) azpimarratzen zutena, ikasleengandik gertu dagoen testuingurua ezagutzea, hain zuzen ere. Horrela, eduki teorikoak lantzeaz gain, hala nola, arrisku-faktoreak, uholdeen aurkako neurri babesgarriak edo giza inpaktuak, gure eskualdeko problematika konkretuak lantzen dira, ikasleen interesa pizteko pentsatuta daudenak, alegia. Aspektu hauek dira, bereziki, konpetentzietan oinarritutako hezkuntzak bilatzen dituenak, Pedrinaci-ren lanean (2013) aipatzen den bezala, zer jakin bezain inportantea da nola egiten jakitea. Horretaz gain, aipatu bezala, badira jarduera asko ikasleen gogoeta bultzatzera bideratu direnak, bai eta ikasleen parte hartzea eta talde lana bultzatzen dutenak. Azken hau oso garrantzitsua da, ikasleen arteko konpetentzia baino, elkarrekintza bultzatzeko beharra dagoelako (Aguerri eta Bravo-Torrija, 2017).

Beste alde batetik, ikasle zientifikoki konpetenteak hezi nahi baldin baditugu, zientziaren arlo guztiak hartu behar ditugu kontuan. Beraz, zientziaren konpetentzia espezifikoak lantzea ezinbestekoa da (Aguerri eta Bravo-Torrija, 2017). Konpetentzia hauen artean, ikerketa zientifikoak egiteko gaitasuna egongo litzateke, unitate didaktiko honen 11. jardueran proposatzen den bezalakoa, adibidez. Kasu honetan, ikerketa hori egiteko landa irteera bat egitea proposatu da, gure inguruneko ibaiak sakonki ezagutzeko aukera paregabea delako. Hala ere, horrelako jarduerak ez dira oso ohikoak hezkuntza formalean, izan ere, irakaslearen aldetik esfortzu oso handia exijitzen dute eta ikastetxe asko ez daude prest haien programan horrelako ekintzak barneratzeko (Martínez eta Gil, 2014).

Proposamen didaktiko hau Euskal Autonomia Erkidegoko Batxilergoko bigarren mailako ikasleentzako oso baliagarria izan daitekeen arren, zailtasun batzuk ekar ditzake berarekin. Batetik, ikerketako emaitzetan ikusi dugun bezala, ikasleen interesa gaiarekiko ez da espero bezain handia (ikasleen \% 61-ak baino ez du adierazi informazio gehiago jasotzea gustatuko litzaiokeela), izan ere, askok gertuko kontua izango ez balitz bezala kontsideratzen dute (ikasleen \% 19-ak baino ez du pentsatzen uholdeak Euskal Herrian maiz gertatu daitezkeenik). Hori arazo handia suertatu daiteke unitate hau inplementatzerakoan, ikaslearen rol aktiboa eskatzen duelako momentu guztietan, eta parte hartze aktibo hori gabe, zaila bilakatu daiteke ikaskuntza- 
irakaskuntza prozesua. Hala ere, planteatu diren jarduerak Euskal Herriko testuingurura egokitu direnez, arazo hori murriztea espero da, gertuko kontua dela ikusterakoan, ikasleen interesa handiagotzea espero baita.

Bestetik, diseinatutako sekuentziaren luzera 9 saiotakoa da gutxi gora behera. Hau arazo bat bilakatu daiteke kontuan hartzen baldin badugu Batxilergoko bigarren mailako Lurraren eta ingurumenaren zientziak irakasgaian curriculumak ezartzen duen eduki karga handia. Maila honetan gai asko jorratu behar dira, eta beharbada gai bakoitzari hainbeste saio dedikatzea ezinezkoa izan daiteke. Hala ere, gure gizartean hain gertu dugun arazo bat izanik eta geroz eta maiztasun handiagoz gertatzen ari direla jakinik, uholde-arriskuak sakontasunez lantzea eta modu egokian ulertzea ezinbestekotzat hartzen da lan honetan. Izan ere, batezbeste, Europan, hurrengo 3 hamarkaden buruan uholde maiztasuna bikoiztu egingo dela aurreikusten da Aldaketa klimatikoaren ondorioz (Alfieri et al., 2015).

Azkenik, sarreran aipatu den bezala, proposamen didaktikoa ikastetxe batean inplementatzeko aukerarik egon ez denez, ezin izan da ebaluatu. Horretaz gain, ezin izan da teorian ikusi diren aspektu guzti hauek Euskal Autonomia Erkidegoko ikastetxe bateko ikasleengan duten eragina frogatu. Beraz, nahiz eta egindako proposamena arlo honetako aurreko lanetan aipatzen diren alderdi teoriko nagusitan oinarritzen den, ezin izan da jakin zein den bere hezkuntza balioa. Etorkizunera begira, lan hau ikastetxe batean inplementatzea komenigarria izango litzateke, honen emaitzak ebaluatu ahal izateko. Horrela, doiketak egitea posiblea izango litzateke, ikastetxe bakoitzeko testuingurura ahalik eta gehien egokitzeko.

\section{Ondorioak}

Honako ondorio hauek lortu dira ikerlan honetan:

1. Batxilergoko bigarren mailako ikasleek uholde-arriskuen aurreko pertzepzio- eta ezagutza-maila baxuak dituzte.

2. Nahiz eta Lurraren eta ingurumenaren zientziak irakasgaia ikasi eta ikasten ez duten ikasleen artean ezberdintasuna nabaritu den pertzepzio eta ezagutzan, ezberdintasun hauek ez dira esanguratsuak izan.

3. Arrisku-maila altuko eta baxuko herrietan bizi diren ikasleen pertzepzio eta ezagutzetan ezberdintasunak antzeman badira ere, ez dira estatistikoki esanguratsuak izan.

Horretaz gain, azpimarratzekoa da eskolak uholde-arriskuen kudeaketan hartzen duen paper garrantzitsua, ikasleen pertzepzio-maila handiagotzen laguntzen duelako, bai eta ezagutza-maila handitzen ere. Ezagutza hori esanguratsua eta sendoa izateko, uholdeak bere testuinguruan ikastearen garrantzia ere nabarmendu behar da. Izan ere, uholdeak ibaiaren dinamika konplexuaren barruan direla jakin behar dute, ibaiaren eraldaketak direlako eta hori jakinda bakarrik lortuko da uholde-arriskuen kudeaketa egokia egitea.

\section{Bibliografia}

20/2016 Errege Dekretua, urtarrilaren 15ekoa, zeinaren bidez, Kantauri Mendebaldeko Demarkazio Hidrografikoaren eta Espainiako zatiko Kantauri Ekialdeko Demarkazio Hidrografikoaren Uholdearriskua Kudeatzeko Planak onartzen direnak. 
236/2015 dekretua, abenduaren 22koa, Oinarrizko Hezkuntzaren curriculuma zehaztu eta Euskal Autonomia Erkidegoan ezartzen duena. Euskal Herriko agintaritzaren aldizkaria, 2016ko urtarrilaren 15a, 9 zk.

903/2010 Errege Dekretua, uztailaren 9koa, zeinaren bidez, uholdeen ebaluazioa eta arriskuen kudeaketa egiten den.

Aguerri, M. eta Bravo-Torrija, B. (2017). El uso de pruebas en la resolución de problemas reales en $4^{\circ}$ de ESO: ¿debemos dragar el río Ebro? Revista Eureka sobre Enseñanza y Divulgación de las Ciencias, 14(2), 302-316.

Alfieri, L., Burek, P., Feyen, L., eta Forzieri, G. (2015). Global warming increases the frequency of river floods in Europe. Hydrology and Earth Systems Sciences, 19, 2247-2260

Arribas, M. (2004). Diseño y validación de cuestionarios. Matronas profesión, 5(17), $23-29$.

Ausubel, D., Novak, J. eta Hanesian, H. (1978). Educational Psychology: A Cognitive View (2nd Ed.). New York: Holt, Rinenhart \& Winston.

Bach, J. eta Márquez, C. (2017). Fundamentos conceptuales y didácticos: El estudio de los fenómenos geológicos desde una perspectiva sistémica. Enseñanza de las Ciencias de la Tierra, 25(3), 302-309.

Bosschaart, A., Kuiper, W., van der Schee, J. eta Schoonenboom, J. (2013). The role of knowledge in students' flood-risk perception. Natural Hazards, 69, 1661-1680.

Bosschaart, A., van der Schee, J., Kuiper, W. eta Schoonenboom, J. (2016). Evaluating a flood-risk education program in the Netherlands. Studies in Educational Evaluation, 50, 53-61.

Camacho, H., Casilla, D. eta Finol de Franco, M. (2008). La indagación: una estrategia innovadora para el aprendizaje de procesos de investigación. Laurus, 14(26), 284-306.

Cardak, O. (2009). Science Students’ Misconceptions of the Water Cycle According to their Drawings. Journal of Applied Sciences, 9(5), 865-873.

Challies E., Newing, J., Thaler, T., Kochskämper E. eta Levin-Keitel, M. (2016). Participatory and collaborative governance for sustainable flood risk management: An emerging research agenda. Environmental science \& policy, 55, 275-280.

Díaz Moreno, N. eta Jiménez-Liso, M. R. (2012). Las controversias sociocientíficas: temáticas e importancia para la educación científica. Revista Eureka sobre Enseñanza y Divulgación de las Ciencias, 9(1), 5470.

Euskalmet (2011). Euskadiko klimatologia. Ezaugarri geografikoak. Eskuragarri: http://www.euskalmet.euskadi.eus/s075853x/eu/contenidos/informacion/car_relieve/eu_7263/eu_relieve.html

Finnis, K., Johnston, D., Ronan, K., eta White, J. (2010). Hazard perceptions and preparedness of Taranaki youth. Disaster Prevention and Management, 19(2), 175-184.

González, M., Valonge, A., Brusi, D. eta Alfaro, P. (2014). ¡Prevenir las catástrofes! Simulando la gestión de los riesgos naturales. Informe inédito. 
Harlen, W. (Ed.) (2010). Principles and big ideas of science education. Association for Science Education.

Hernández, R., Fernández, C. eta Baptista, L. (2010). Metodología de la investigación (5. edizioa). México: Mc Graw Hill.

Ibisate, A., Ollero, A. eta Ormaetxea, O. (2000). Las inundaciones en la vertiente cantábrica del País Vasco en los últimos veinte años: principales eventos, consecuencias territoriales y sistemas de prevención. Serie Geográfica, 9, 177-186.

López Aymes, G. (2012). Pensamiento crítico en el aula. Docencia e Investigación, 22, 41-60.

Lukas, J.F. eta Santiago, K. (2016). Hezkuntza Ebaluazioa. Bilbo: Euskal Herriko Unibertsitatea.

Martínez, M. B. eta Gil, M. J. (2014). Investigación educativa. El río: un tema cotidiano para el aula de ciencias. Enseñanza de las Ciencias de la Tierra, 22(3), 257-266.

Olcina, J. (2009). Cambio climático y riesgos climáticos en España. Investigaciones geográficas, 49, 197-220.

Oliva, J. M., Franco-Mariscal, R. eta Almoraima, M. L. (2016). Las pruebas de acceso a la universidad y la inclusión de contenidos Ciencia-Tecnología-Sociedad en los currículos de Bachillerato. Indagatio Didáctica, 8(1), 1.

Pahl-Wostl, C. (2006). The importance of social learning in restoring the multifunctionality of rivers and floodplains. Ecology and Society, 11(1), 10.

Pedrinaci, E. (2013). Fundamentos conceptuales y didácticos: Alfabetización en Ciencias de la Tierra y competencia científica. Enseñanza de las Ciencias de la Tierra, 21(2), 208-214.

Pérez-Villalobos, H. A., Torres-Salas, M. I. eta Gómez-Lépiz, A. (2017). El aprendizaje por indagación como opción para desarollar la unidad de hidrostática del programa de física de décimo año, de la Educación Diversificada de Costa Rica. Revista Ensayos Pedagógicos, 12(2), 169-193.

Robles, M., Wilches, G., Näslund-Hadley, E., Ramon, M.C. eta Paredes, J.R. (2015). Gestión del riesgo en la escuela. Banco Interamericano de Desarrollo en educación sobre el cambio climático (BID).

Sayers, P., Li, Y., Galloway, G., Penning-Rowsell, E., Shen, F., Wen, K., Chen, Y. eta Le Quesne, T. (2013). Flood Risk Management: A Strategic Approach. Paris, UNESCO.

Selby, D. eta Kagawa, F. (2012). Disaster risk reduction in school curricula: case studies from thirty countries. UNICEF, Switzerland.

Shaw, R., Shiwaku, K., Kobayashi, H. eta Kobayashi, M. (2004). Linking experience, education, perception and earthquake preparedness. Disaster Prevention and Management, 13, 39-49.

Siegrist, M. eta Gutscher, H. (2006). Flooding risks: a comparison of lay people’s perceptions and expert's assessments in Switzerland. Risk Analysis, 26, 971-979.

Sjöberg, L., Moen, B. eta Rundmo, T. (2004). Explaining risk perception: an evaluation of the psychometric paradigm in risk perception research. Rotunde 84 Norwegian University of Science and Technology, Department of Psychology, Trondheim. 
Uraren euskal

agentzia.

Eskuragarri:

http://www.uragentzia.euskadi.eus/u81-

0003/eu/contenidos/informacion/2011_epri/es_doc/index.html. 2019-11-03.

Wagner, K. (2007). Mental models of flash floods and landslides. Risk Analysis, 27(3), 671-685. 

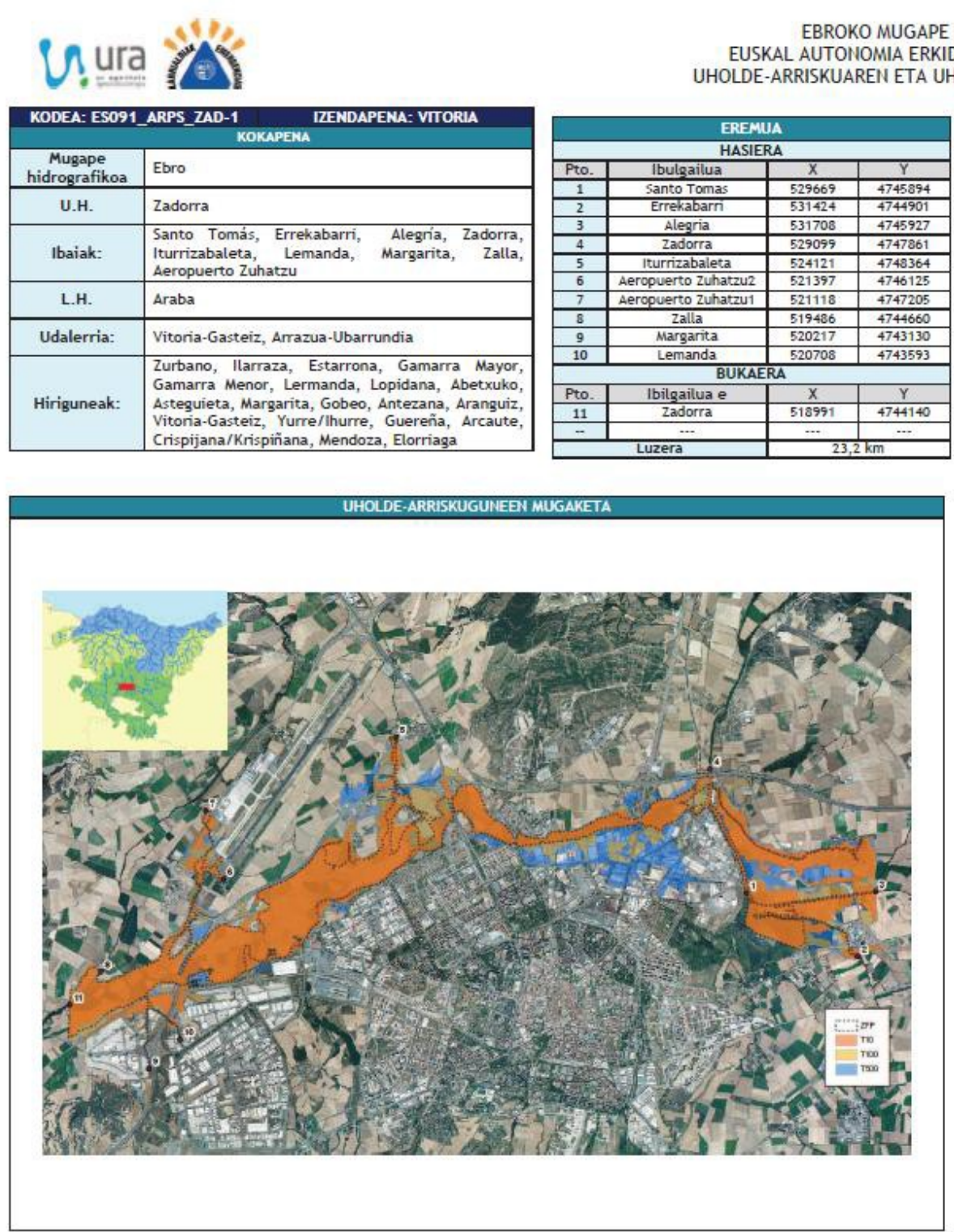

EBROKO MUGAPE HIDROGRAFIKOA

EUSKAL AUTONOMIA ERKIDEGOKO ARTEKO ARROAK UHOLDE-ARRISKUAREN ETA UHOLDE-KALTERAGIIIEN MAPAK

2013KO EKAINA

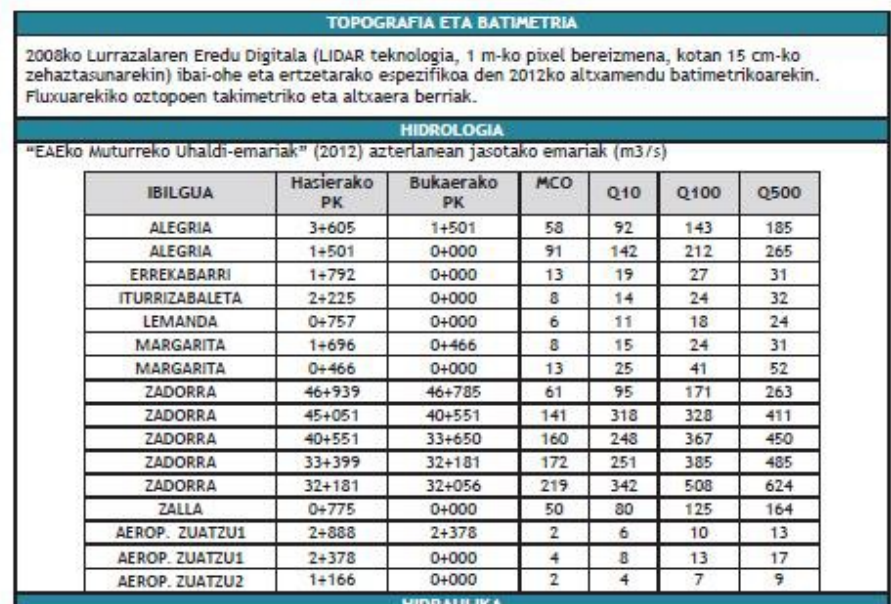

HEC-RAS softwarearen bidez egindako erregimen egonkor, mantso eta dimentsio bakarreko simulazioa. ibilguaren zimurtasuna cowan formulazioarekin zenbate
arabera. Kalkuluari is zubi eta 5 presa txiki gehitu zaizkio.

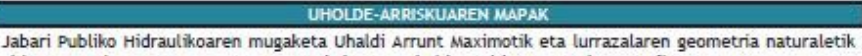
abiatuta, Zaintza eta Zortasun eremuak barne. Uholde-arriskuguneen kartografia $T=10,100$ eta 500
itzultze-aldietarako eta Lehentasunezko fluxu-guneak, $9 / 2008$ E.D. an jasotako definizioaren arabera. Jabari Publiko Hidraulikoaren, Uholde-arriskuguneen eta Lehentasunezko Fluxven-guneen mugaketen azken doikuntza irizpide geomorfologikoak jarraituz: erliebeare
ebolusioaren azterketa, ingurune-alderciak integratuz aldi berean.

biztanleriarenganako erasanak biztanleria enrroldatuari eta erasandako bizitegi-eraikuntzei dagozkie. spero diren galera ekonomikaak, hurrengo elementu zaurgarnetako sakoneraren arabera aztertu dira: zenbatesteko Katastroaren eta Aseguru-konpentsazio Partzuergoaren informazioa erabili da. Ingurune-
arrisku adierazgarrienak ere identifikatzen dira, zaurgarri diren elementu puntualak barne.

\begin{tabular}{|c|c|c|}
\hline \multicolumn{3}{|c|}{ KALTERAGINEN LABURPEKA } \\
\hline \multirow{2}{*}{\multicolumn{2}{|c|}{$\begin{array}{l}\text { Uholde-arriskuguneetan erasan } \\
\text { daitekeen biztanle kopurua. } \\
\text { Uholde-arriskuguneetan espero den }\end{array}$}} & 224biztanle/urteo \\
\hline & & 1.955.840 E/urte \\
\hline \multirow{3}{*}{$\begin{array}{l}\text { Erasandako } \\
\text { Komunikazio bideak }\end{array}$} & $\frac{\text { inikoa }}{\text { T10 }}$ & $A-2134, A-3302, A-3008, A-4001, N-104, N-1, N-622, A-4001$ \\
\hline & T100 & $\begin{array}{l}A-2134, A-3302, A-3008, A-4001, N-104, N-1, N-622, A-4001, \\
A-3002 \\
\text { Euskatran }\end{array}$ \\
\hline & T500 & $\begin{array}{l}\text { A-2134, A-3302, A-3006, A-4001, N-104, N-1, N-622, A-4001, } \\
\text { A-3002, Euskotran, RENFE, N-240 }\end{array}$ \\
\hline \multicolumn{2}{|c|}{ 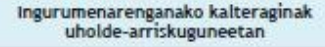 } & $\bar{\nabla}_{\text {UHA }} \Gamma$ EUT $\Gamma$ Arrisku kimikodun enpresak \\
\hline \multicolumn{2}{|c|}{$\begin{array}{l}\text { Plan Hidrologikoaren erregistroan } \\
\text { dauden Babestutako Eremuekin egon } \\
\text { daitezkeen interferentziak }\end{array}$} & 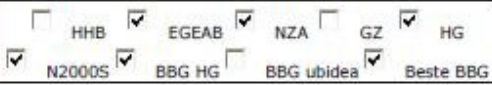 \\
\hline
\end{tabular}




\begin{tabular}{|c|l|}
\hline KODEA: ES17-BIZ-IBA-01 KOKAPENA \\
\hline $\begin{array}{c}\text { Mugape } \\
\text { hidrografikoa }\end{array}$ & Ekialdeko Kantaurialdea \\
\hline U.H. & Ibaizabal \\
\hline Ibaiak: & Ibaizabal, Kadagua, Gobela, Udondo \\
\hline L.H. & Bizkaia \\
\hline Udalerria: & Bilbao, Erandio \\
\hline Hiriguneak: & Bilbao, Altzaga, Lutxana-Enekuri \\
\hline
\end{tabular}

KAITTAURI EKIALDEKO MUGAPE HIDROGRAFIKOA EUSKAL AUTONOMIA ERKIDEGOKO BARNEKO ARROAK
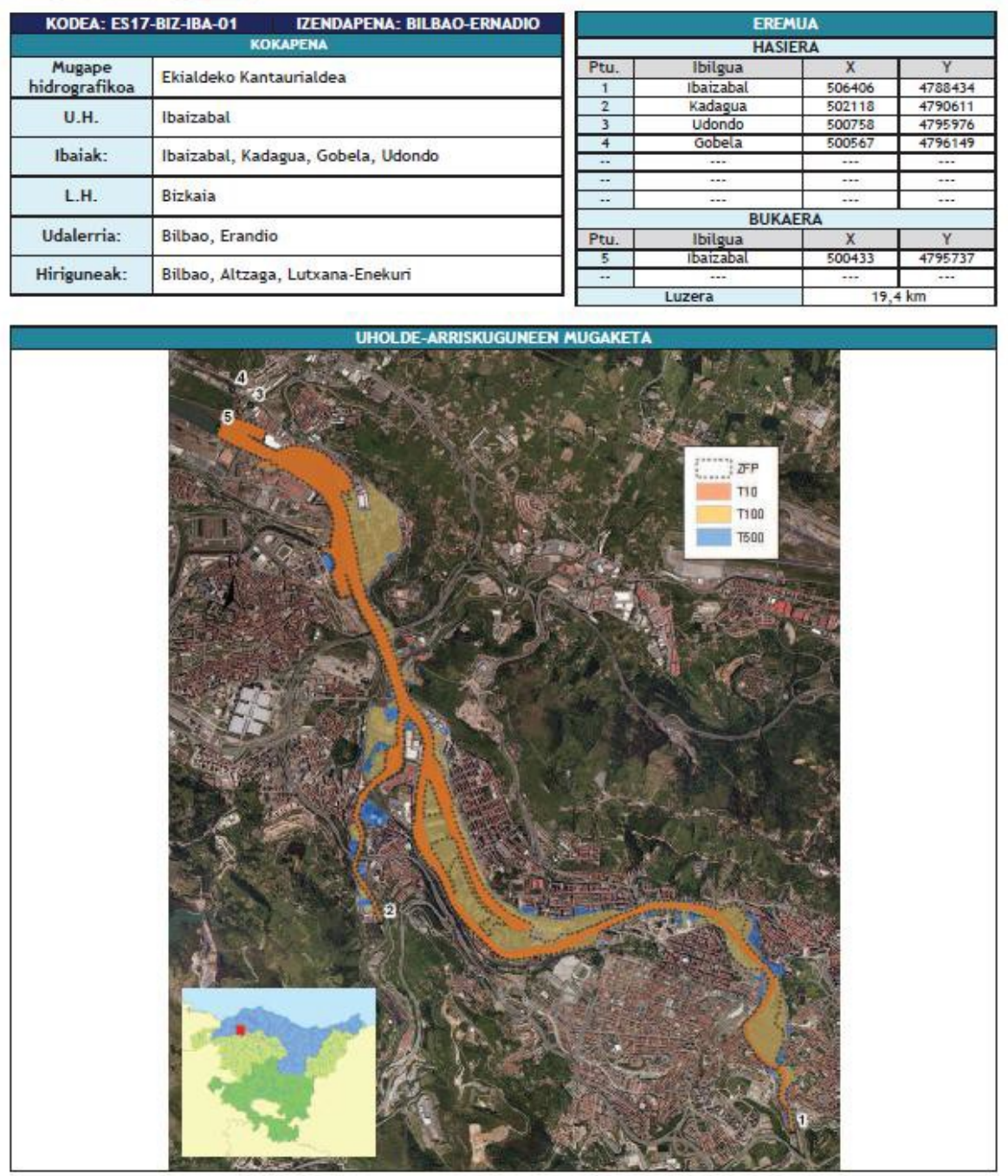

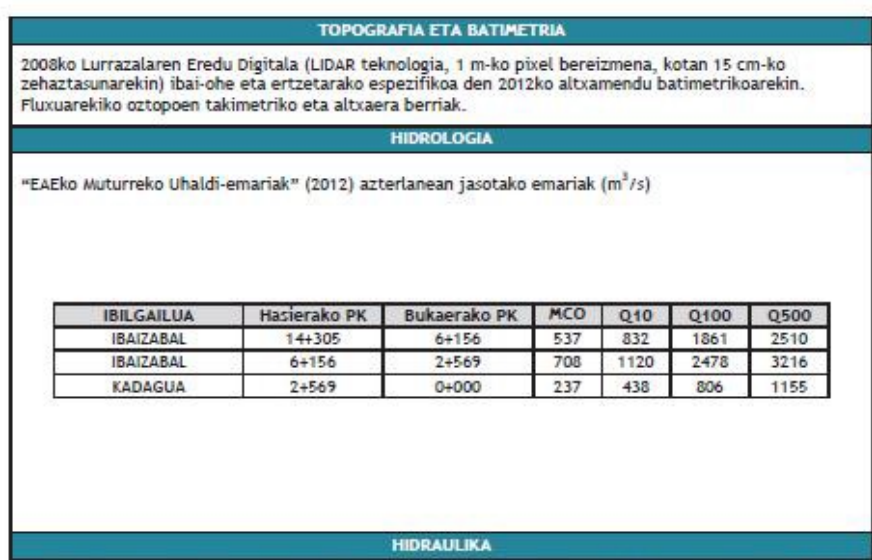

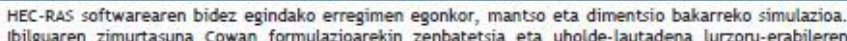

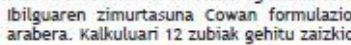

Jabari Publiko Hidraulikoaren mugaketata Uhaldi Arrunt Maximotik eta lurrazalaren geometria naturaleteth

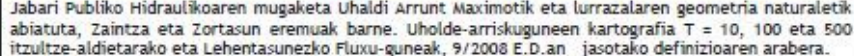

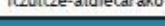

Jabari Publiko Hidraulikoaren, Unolde-arrikugunneen eta Lehentasunezko Fluxven-guneen mugaketeren

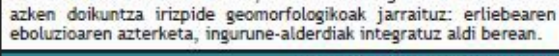

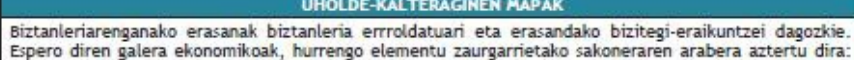

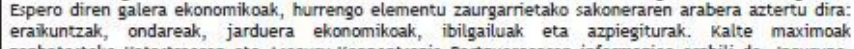

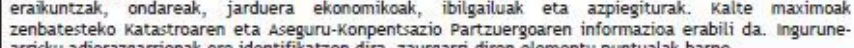

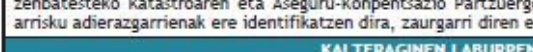

\begin{tabular}{|c|c|c|}
\hline \multicolumn{3}{|c|}{ KALTERAGINEM LABURPENA } \\
\hline \multirow{2}{*}{\multicolumn{2}{|c|}{ 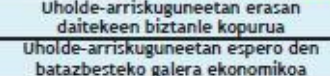 }} & 727 biztanle/urte \\
\hline & & 5.261.894 E/urte \\
\hline \multirow{3}{*}{$\begin{array}{l}\text { Erasandako komunikazio } \\
\text { bideak }\end{array}$} & T10 & \\
\hline & $T 100$ & B1-711, Metro Bilbao, RENFE Barakaldo, Euskotran Bilbao \\
\hline & T500 & B1-711, Metro Bilbao, RENFE Barakaldo, Euskotran Bilbaa \\
\hline \multicolumn{2}{|c|}{$\begin{array}{l}\text { Ingurumenarenganako kalteraginak } \\
\text { uholde-arriskuguneetan }\end{array}$} & $\Gamma$ UHA $\Gamma_{\text {EUT }} \Gamma$ Amisku kimikodun enpresak \\
\hline \multicolumn{2}{|c|}{$\begin{array}{l}\text { Plan Hidrologikoaren erregistroan } \\
\text { dauden Babestutako Eremuekin egon } \\
\text { daitezkeen interferentziak }\end{array}$} & $\Gamma \Gamma_{\text {HHB }}\left\ulcorner{ }_{\text {EGEAB }}\left\ulcorner{ }_{\text {BG }}\left\ulcorner\right.\right.\right.$ GZ $\left\ulcorner{ }_{\text {HG }}\right.$ \\
\hline \multicolumn{2}{|c|}{ Bestelako elementuak } & Intermutua Euskadi \\
\hline
\end{tabular}




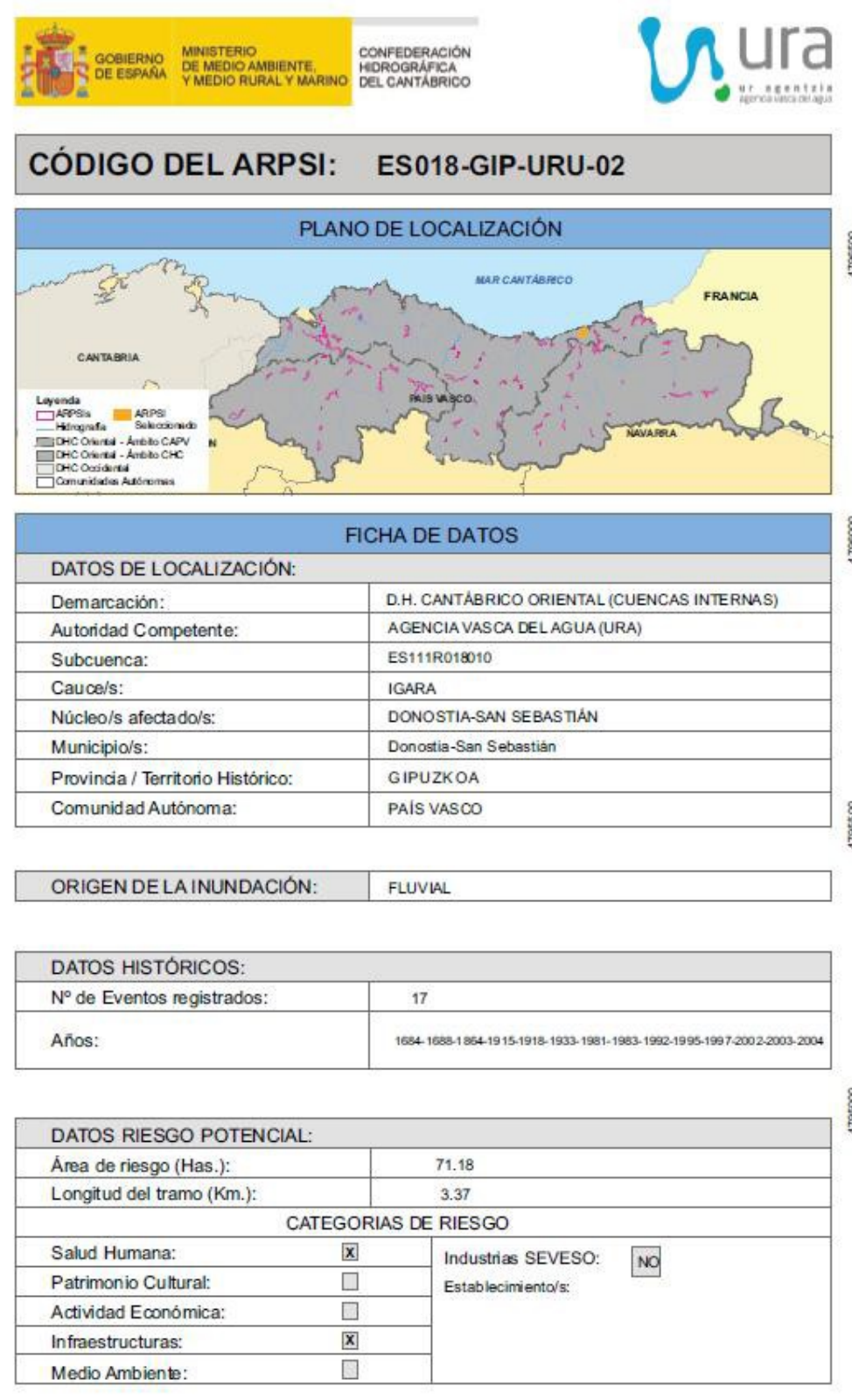

ÁREAS DE RIESGO POTENCIAL SIGNIFICATIVO DE INUNDACIÓN (ARPSIs) Sistema Nacional de Cartografía de Zonas Inundables
en la Demarcación Hidrográfica del Cantábrico Oriental

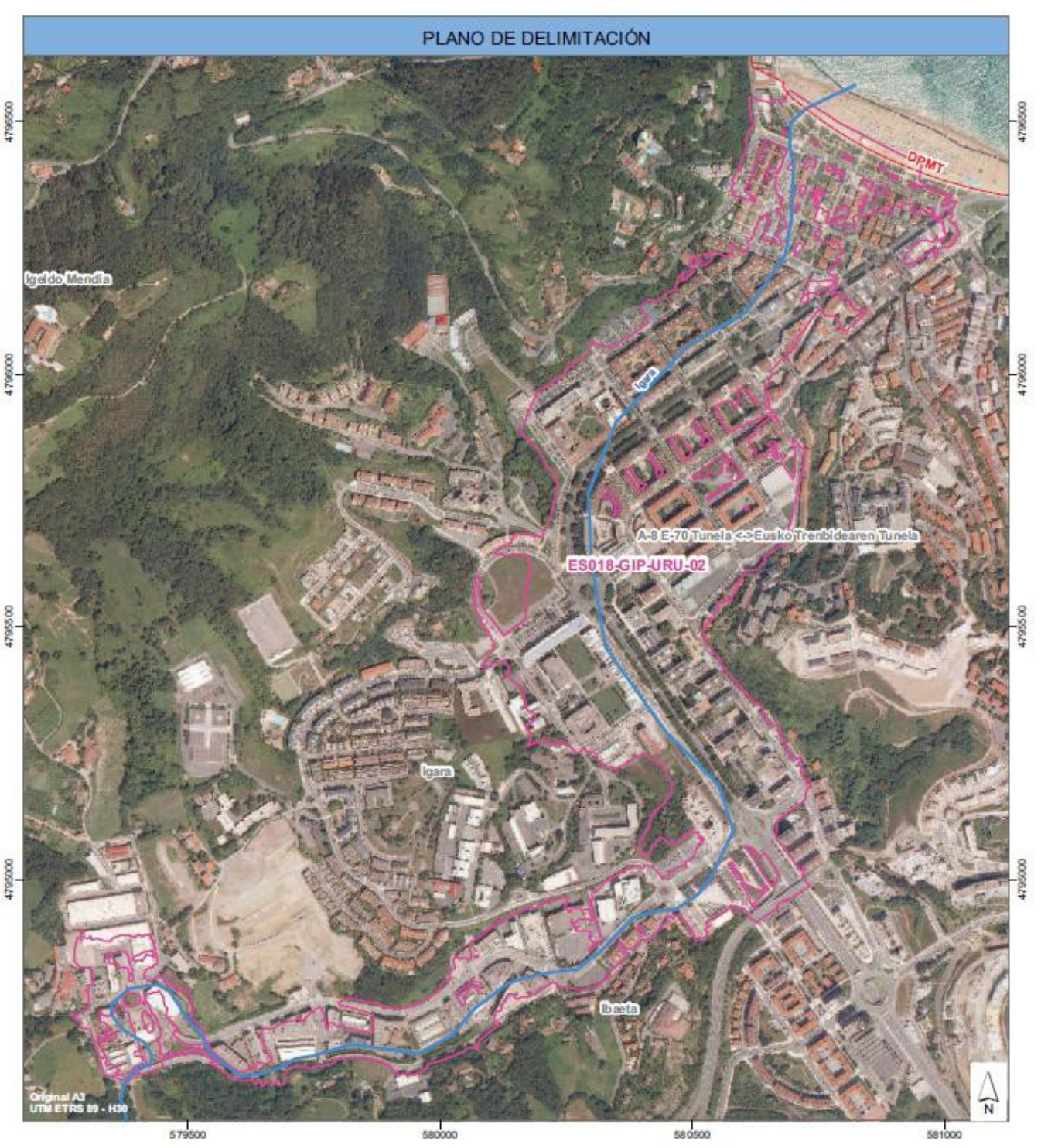


I I. ERANKSINA. Unibertsitaterako sarrera frogaren galdera tipoa.

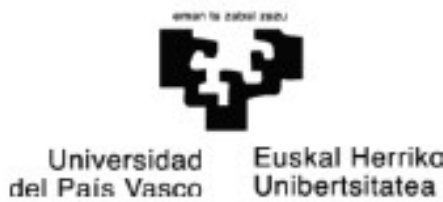

\section{UNIBERTSITATERA SARTZEKO PROBAK \\ 2015eko EKAINA}

LURRAREN ETA

INGURUMENAREN ZIENTZIAK
PRUEBAS DE ACCESO A LA UNIVERSIDAD

JUNIO 2015

\section{CIENCIAS DE LA TIERRA Y MEDIOAMBIENTALES}

\section{GALDERA}

Jarraian, ibai baten profil eskematikoa duzu. Gainera, prezipitazio kopurua eta elurkota bi egoera desberdinetan eta ondoz ondoko zortzi egunetan adierazten dituzten bi taula dituzu. Demagun bi egoerak euri-sasoiaren ondoren gertatzen direla. Aztertu datuak, eta erantzun beheko galderei:

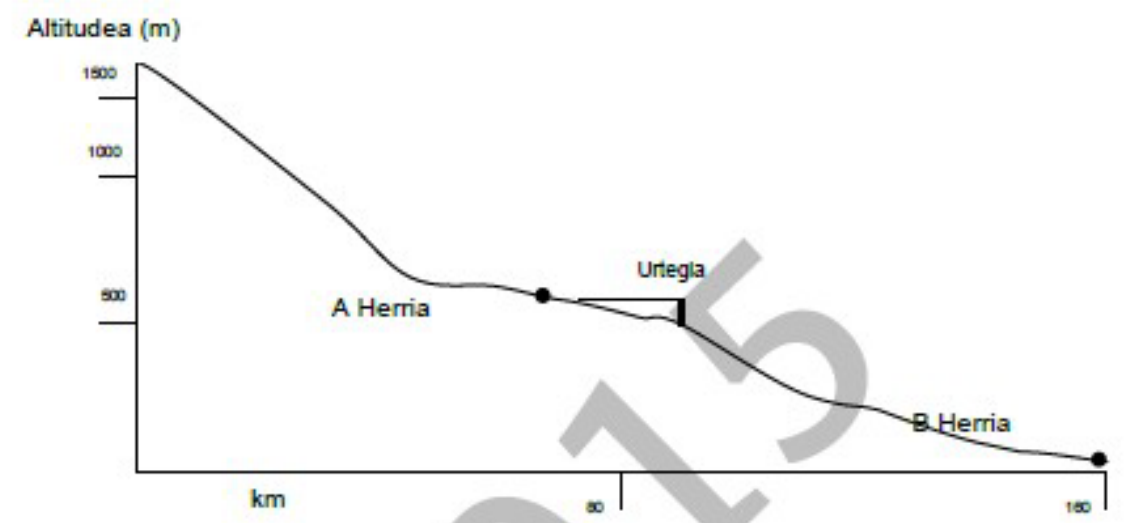

\begin{tabular}{|c|c|c|c|c|c|c|c|c|}
\hline \multicolumn{10}{|c|}{ I. egoera } \\
\hline Eguna & 1 & 2 & 3 & 4 & 5 & 6 & 7 & 8 \\
\hline Prezipitazioa l/m ${ }^{2}$ & 0 & 20 & 45 & 40 & 25 & 0 & 0 & 0 \\
\hline Elur-kota $(\mathrm{m})$ & 500 & 300 & 0 & 300 & 400 & 1.800 & 2.200 & 2.200 \\
\hline
\end{tabular}

\begin{tabular}{|c|c|c|c|c|c|c|c|c|}
\hline \multicolumn{9}{|c|}{ II. egoera } \\
\hline Eguna & 1 & 2 & 3 & 4 & 5 & 6 & 7 & 8 \\
\hline Prezipitazioa l/m ${ }^{2}$ & 0 & 20 & 45 & 40 & 25 & 0 & 0 & 0 \\
\hline Elur-kota $(\mathrm{m})$ & 1.200 & 1.300 & 1.500 & 1.500 & 1.300 & 1.500 & 1.500 & 1.500 \\
\hline
\end{tabular}

a) (0,5 puntu) Ematen diren datuak ikusita, deskriba ezazu bi egoeretako baldintza atmosferikoen bilakaera (prezipitazioa eta tenperatura-oszilazioa, elur-kotaren aldaketekin erlazioan) egunetan zehar.

b) (1,5 puntu) Zer arrisku sor lezake/litzake B Herrian egoera bakoitzaren bilakaerak? Kasu bakoitzean, irudikatutako denborazko seriearen zer unetan gertatuko lirateke (hasieran, egun jakin batetik aurrera edo azkenean)? Arrazoitu ezazu erantzuna.

c) (1,5 puntu) Adierazi diren egoeretan, baloratu zer arrisku duen B herriko populazioak urtegia beteta dagoenean eta maila txiki-ertainetan dagoenean. Arrazoitu erantzuna. 
I I I. ERANSKINA. Batxilergoko 2. mailako ikasleei emandako galdetegia.

Sexua: Neska $\square$ Mutila $\square$ Beste bat $\square \quad$ Adina:
I kastetxea:
Herria:
$-\quad-\quad-\ldots-\ldots-\square-\square$

1. Adierazi ezazu $\mathrm{X}$ batekin zein den zure adostasun- edo desadostasun- maila baieztapen hauekiko.

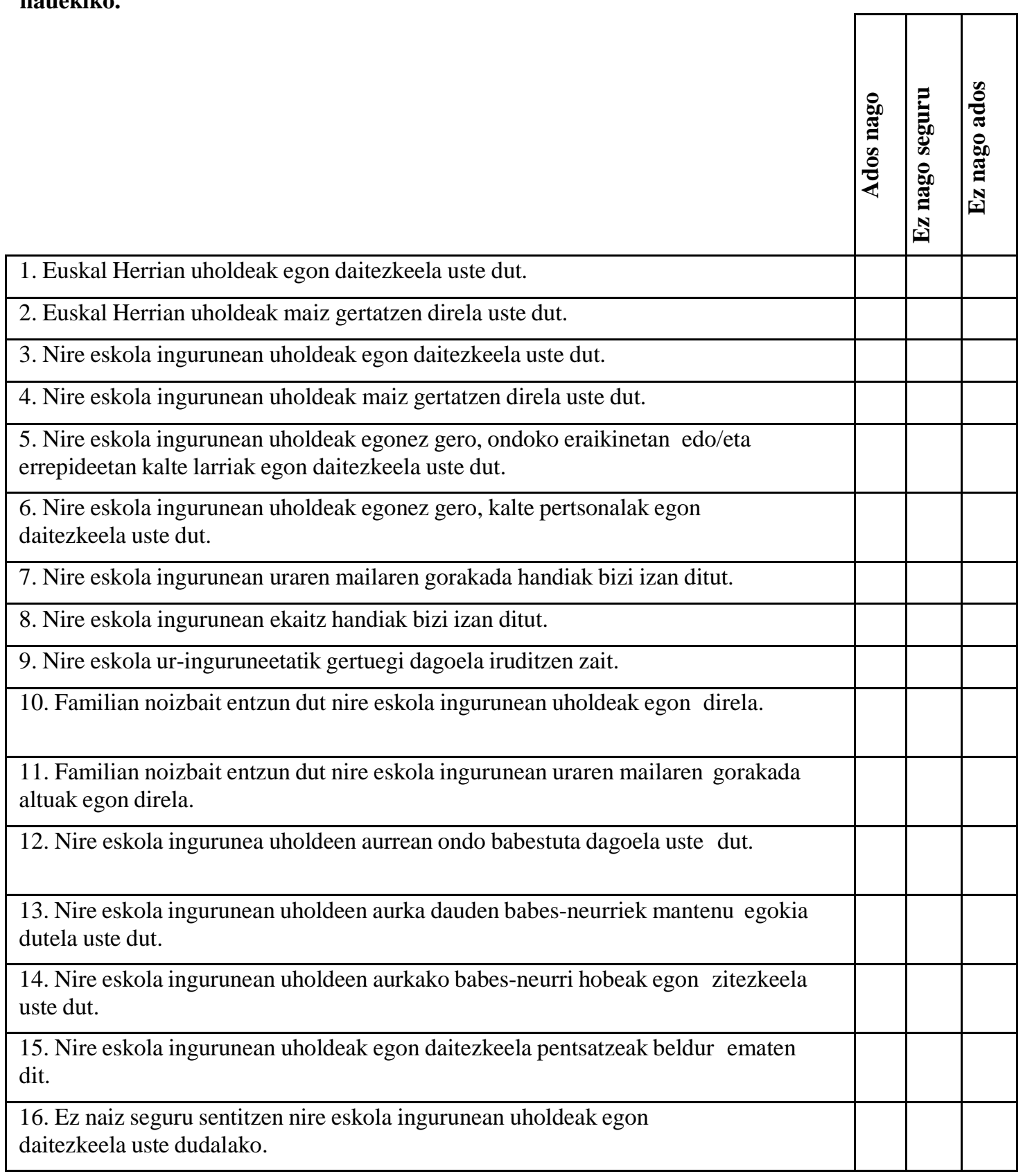


2. Irudika ezazu zure herria uholdeengandik babesten dituzten neurriak eta uholdeak eragin ditzaketen eragileak. Marraztu itzazu burura datozkizun neurri eta eragile guztiak (naturalak zein artifizialak) eta idatz itzazu haien izenak.

3. Erantzun ondorengo galderei. Hautatu itzazu, zure ustez, egokiak diren erantzun guztiak. Gogoratu erantzun bat baino gehiago aukeratu dezakezula!

1) Zure eskualdean uholde-arriskua murrizteko zein neurri proposatuko zenuke?
a) Urtegiak eraikitzea
b) Ibaiak kanalizatzea
c) Uholde lautadak errespetatzea eta berreskuratzea
d) Uholdeak pairatzeko joera duten eremuetan gehiago ez eraikitzea

2) Zure ustez, zeintzuk dira uholdeak eragin ditzakeen arrisku-faktoreak?
a) Landaretza urria ibai bazter eta mendietan
b) Eskualdeko klimatologia
c) Topografia aldapatsua
d) Ibaiaren sorburuaren eta itsasoaren arteko distantzia laburra
e) Aldaketa klimatikoa

3) Uholdeak guztiz aurresan ezin daitekeen fenomeno naturala den arren, giza jarduerek uholdeak gertatzeko probabilitatea eta haien inpaktua handitzen dute. Baina, nola?
a) Uraldietako ubideak betez
b) Hirietako diseinu okerra eginez (adz. zubiak gaizki diseinatzeagatik)
c) Behar ez den tokietan eraikinak eta errepideak eraikiz
d) Ibaien mantenu desegokia eginez 


\section{Adierazi ezazu $X$ batekin zure ustez egokiena den aukera.}

\begin{tabular}{|l|l|l|l|}
\cline { 2 - 4 } \multicolumn{1}{l|}{} & & & \\
\hline Nire eskolan uholdeen inguruko informazio nahikoa jasotzen dudala uste dut. & & & \\
\hline Eskolatik kanpo uholdeen inguruko informazio nahikoa jasotzen dudala uste dut. & & & \\
\hline Uholdeen aurkako babesen inguruan informazio nahikoa jasotzen dudala uste dut. & & & \\
\hline Uholde-arriskuen inguruan informazio gehiago jasotzea gustatuko & & & \\
litzaidake. & & & \\
\hline
\end{tabular}

I. ERANSKINA: Irteeran taldeka bete beharreko fitxak (ibaiaren datu orokorrak eta ibaiaren ezaugarriak eta erriberak).

\section{1.fitxa: ibaiaren datu orokorrak}

Ibaiaren izena:

Ibai nagusia edo ibaiadarra da?

Zer arro hidrografikoren parte da?

Ibaiaren luzera:

\section{Ibaiaren erabilerak:}

- Urtegiren bat, edo ibaiaren ibilgu naturala oztopatzen duen bestelako eraikuntzaren bat (kanalak, fabrikak...) al dago? 